\title{
River flow and ammonium discharge determine spring phytoplankton blooms in an urbanized estuary
}

\author{
Richard Dugdale $^{\mathrm{a}, *}$, Frances Wilkerson ${ }^{\mathrm{a}}$, Alexander E. Parker ${ }^{\mathrm{a}}$, Al Marchi ${ }^{\mathrm{a}, \dagger}$, Karen Taberski ${ }^{\mathrm{b}}$ \\ ${ }^{a}$ Romberg Tiburon Center, San Francisco State University, 3152 Paradise Drive, Tiburon, CA 94920, United States \\ ${ }^{\mathrm{b}}$ Regional Water Quality Control Board, San Francisco Bay Region, 1515 Clay St., Suite 1400, Oakland, CA 94612, United States
}

\section{A R T I C L E I N F O}

\section{Article history:}

Received 18 May 2012

Accepted 28 August 2012

Available online $\mathrm{xxx}$

\section{Keywords:}

wastewater treatment

phytoplankton

ammonium

estuary

bloom

Regional index terms:

USA

California

San Francisco Bay

\begin{abstract}
A B S T R A C T
Nutrient loadings to urbanized estuaries have increased over the past decades in response to population growth and upgrading to secondary sewage treatment. Evidence from the San Francisco Estuary (SFE) indicates that increased ammonium $\left(\mathrm{NH}_{4}\right)$ loads have resulted in reduced primary production, a counterintuitive finding; the $\mathrm{NH}_{4}$ paradox. Phytoplankton uptake of nitrate $\left(\mathrm{NO}_{3}\right)$, the largest pool of dissolved inorganic nitrogen, is necessary for blooms to occur in SFE. The relatively small pool of ambient $\mathrm{NH}_{4}$, by itself insufficient to support a bloom, prevents access to $\mathrm{NO}_{3}$ and bloom development. This has contributed to the current rarity of spring phytoplankton blooms in the northern SFE (Suisun Bay), in spite of high inorganic nutrient concentrations, improved water transparency and seasonally low biomass of bivalve grazers. The lack of blooms has likely contributed to deleterious bottom-up impacts on estuarine fish. This bloom suppression may also occur in other estuaries that receive large amounts of anthropogenic $\mathrm{NH}_{4}$. In 2010 two rare diatom blooms were observed in spring in Suisun Bay (followed by increased abundances of copepods and pelagic fish), and like the prior bloom observed in 2000, chlorophyll accumulated after $\mathrm{NH}_{4}$ concentrations were decreased. In 2010, low $\mathrm{NH}_{4}$ concentrations were apparently due to a combination of reduced $\mathrm{NH}_{4}$ discharge from a wastewater treatment plant and increased river flow. To understand the interactions of river flow, $\mathrm{NH}_{4}$ discharge and bloom initiation, a conceptual model was constructed with three criteria; 1 ) $\mathrm{NH}_{4}$ loading must not exceed the capacity of the phytoplankton to assimilate the inflow of $\mathrm{NH}_{4}, 2$ ) the $\mathrm{NH}_{4}$ concentration must be $\leq 4 \mu \mathrm{mol} \mathrm{L}{ }^{-1}$ to enable phytoplankton $\mathrm{NO}_{3}$ uptake, 3 ) the dilution rate of phytoplankton biomass set by river flow must not exceed the phytoplankton growth rate to avoid "washout". These criteria were determined for Suisun Bay; with sufficient irradiance and present day discharge of 15 tons $\mathrm{NH}_{4}-\mathrm{N} \mathrm{d}^{-1}$ at the upstream wastewater treatment plant (WTP). The loading criterion requires phytoplankton $\mathrm{NH}_{4}$ uptake to exceed $1.58 \mathrm{mmol} \mathrm{m}^{-2} \mathrm{~d}^{-1}$; the concentration criterion requires river flow $>800 \mathrm{~m}^{3} \mathrm{~s}^{-1}$ at the WTP for sufficient $\mathrm{NH}_{4}$ dilution and the washout criterion requires river flow at Suisun Bay $<1100 \mathrm{~m}^{3} \mathrm{~s}^{-1}$. The model and criteria are used to suggest how a reduction in anthropogenic $\mathrm{NH}_{4}$, either by reduced discharge or increased dilution (river flow), could be used as a management tool to restore pre-existing productivity in the SFE and similarly impacted estuaries.
\end{abstract}

(c) 2012 Elsevier Ltd. All rights reserved.

\section{Introduction}

Prior to 1987, phytoplankton blooms occurred regularly in spring and summer in the northern San Francisco Estuary (SFE) (Fig. 1). Ball and Arthur (1979) described the high chlorophyll conditions in Suisun Bay from 1969 to 1979 with mean chlorophyll concentrations of $30-40 \mu \mathrm{g} \mathrm{L}^{-1}$ in spring and $40-100 \mu \mathrm{g} \mathrm{L}^{-1}$ in

\footnotetext{
* Corresponding author.

E-mail address: rdugdale@sfsu.edu (R. Dugdale).

Deceased.
}

summer. Diatoms were the dominant phytoplankton functional group. Phytoplankton blooms of this magnitude are now rare (Jassby, 2008), in spite of increasing inorganic nutrient concentrations delivered to Suisun Bay by the Sacramento River (Parker et al., 2012c). The zooplankton consumer trophic level is now foodlimited (Müeller-Solger et al., 2002; Kimmerer et al., 2005). The lack of blooms has likely contributed to deleterious bottom-up impacts on estuarine fish by lowering the quantity and quality of food for the pelagic food web. Declines in four pelagic fish stocks and the listing of the delta smelt and longfin smelt as endangered and threatened species have been linked to the decline in phytoplankton in the northern SFE (Sommer et al., 2007),

0272-7714/\$ - see front matter ㄷ 2012 Elsevier Ltd. All rights reserved. http://dx.doi.org/10.1016/j.ecss.2012.08.025 


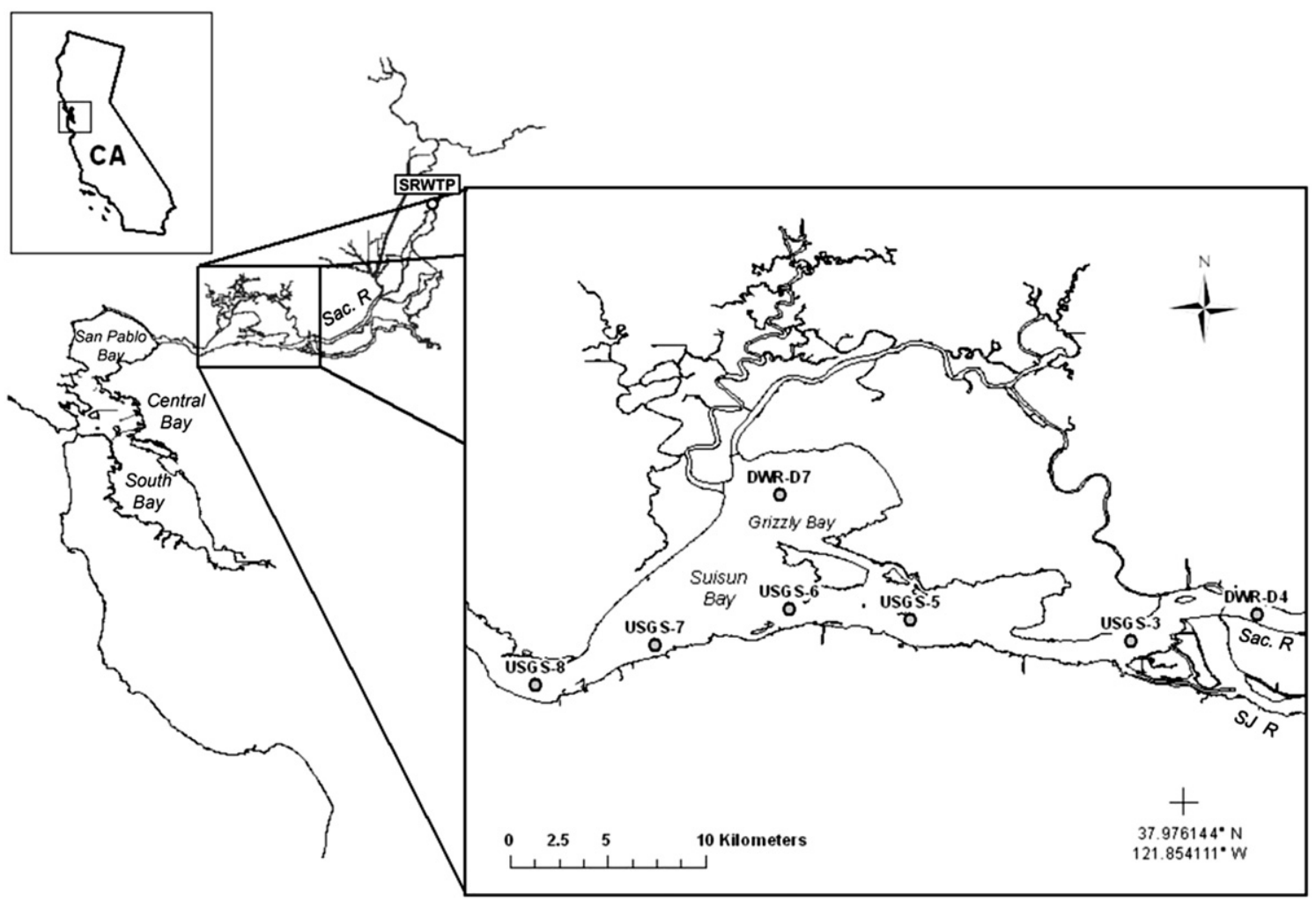

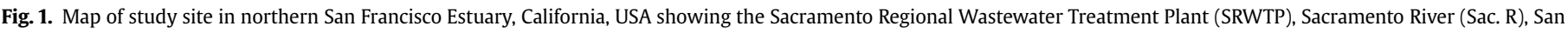
Joaquin River (SJ. R) and the seven sampling stations in Suisun Bay.

a demonstration of the dependence of fishery yield on primary production (Nixon, 1988).

The decline in chlorophyll concentrations began in the early 1980's and blooms became rare after 1987, coincident with the introduction of an invasive clam, Potamocorbula amurensis (Alpine and Cloern, 1992; Jassby et al., 2002). The appearance of $P$. amurensis has been considered the major factor in the disappearance of phytoplankton blooms in Suisun Bay (Alpine and Cloern, 1988; Kimmerer and Orsi, 1996). However any role of Potamocorbula in eliminating phytoplankton blooms during spring is likely minor as clam biomass is low during that season (Greene et al., 2011). The lack of spring phytoplankton blooms in Suisun Bay suggests some other causal agent may suppress phytoplankton activity.

Since 1999, spring blooms have been observed only twice in Suisun Bay, in 2000 (Wilkerson et al., 2006; Kimmerer et al., 2012; Parker et al., 2012b) and recently in 2010 (during this study). A common feature of both blooms in which $30 \mu \mathrm{g} \mathrm{L}^{-1}$ chlorophyll was measured, was a decline in ammonium $\left(\mathrm{NH}_{4}\right)$ concentrations to $\sim 1 \mu \mathrm{mol} \mathrm{L}{ }^{-1}$ (Wilkerson et al., 2006), suggesting a possible link between low $\mathrm{NH}_{4}$ and bloom formation. Ammonium concentrations increased in the northern SFE and in Suisun Bay prior to the clam invasion, coincident with human population increase since the 1970's (Jassby, 2008; Glibert et al., 2011), reflecting increased wastewater discharge from the Sacramento Regional Wastewater Treatment Plant (SRWTP). The SRWTP currently discharges 15 tons $\mathrm{N} \mathrm{d}^{-1}$, largely as $\mathrm{NH}_{4}$, to the inland delta of the SFE and to Suisun Bay (Jassby, 2008; his Fig. 1), a 3-fold increase from 5 tons $\mathrm{N} \mathrm{d}^{-1}$ in 1987.

Elevated $\mathrm{NH}_{4}$ from sewage effluent was implicated in depressed primary production along the California coast (Macisaac et al., 1979), the Delaware Estuary (Yoshiyama and Sharp, 2006), the Scheldt Estuary (Cox et al., 2009), Wascana Creek, Canada (Waiser et al., 2010), and the inner bay of Hong Kong Harbor (Xu et al., 2010). At locations within the SFE, including Suisun Bay, elevated $\mathrm{NH}_{4}$ has been linked to low chlorophyll, low rates of primary production and changes in phytoplankton community structure (Wilkerson et al., 2006; Dugdale et al., 2007; Glibert et al., 2011; Parker et al., 2012a,c).

The well-known inhibition of $\mathrm{NO}_{3}$ uptake by $\mathrm{NH}_{4}$ (e.g. Pennock, 1987) appears to be a key process and a likely causal agent leading to reduced primary production in environments with elevated $\mathrm{NH}_{4}$ concentrations. In the SFE and the Sacramento River, phytoplankton $\mathrm{NO}_{3}$ uptake is inhibited by $\mathrm{NH}_{4}$ (Dugdale et al., 2007; Parker et al., 2012c). The lack of access to $\mathrm{NO}_{3}$ limits primary production (Parker et al., 2012a,c) and the buildup of chlorophyll, i.e. blooms, since $\mathrm{NO}_{3}$ is by far the largest component of the inorganic $\mathrm{N}$ pool, about $80 \%$ in Suisun Bay. The increased $\mathrm{NH}_{4}$ may have also resulted in deleterious changes in the food web structure, e.g. diatoms replaced by cryptomonads and flagellates, large zooplankton replaced by smaller species (Glibert, 2010; Glibert et al., 2011).

Drawing from time-series data of chlorophyll, nutrient concentrations, phytoplankton nitrogen uptake (Wilkerson et al., 2006) and results from enclosure experiments (Dugdale et al., 2007; Parker et al., 2012a), the events leading to a spring phytoplankton bloom in SFE were shown to follow a predictable sequence (Dugdale et al., 2007; Parker et al., 2012a). In early spring, phytoplankton N demand in Suisun Bay is satisfied by $\mathrm{NH}_{4}$ but with low biomass-specific and depthintegrated $\mathrm{NH}_{4}$ uptake rates due to high turbidity and poor irradiance (Parker et al., 2012b). $\mathrm{NO}_{3}$ uptake is low or near zero during this period due to $\mathrm{NH}_{4}$ inhibition. With improved irradiance conditions (via increased water transparency, water column stability or seasonal increase in irradiance), phytoplankton $\mathrm{NH}_{4}$ uptake rates and biomass increase causing water column $\mathrm{NH}_{4}$ concentrations to decrease. Once $\mathrm{NH}_{4}$ decreases to $<4 \mu \mathrm{mol} \mathrm{L}-1$ phytoplankton $\mathrm{NO}_{3}$ uptake is enabled. With continued phytoplankton growth, $\mathrm{NH}_{4}$ concentration is further 
reduced to $\leq 1 \mu \mathrm{mol} \mathrm{L} \mathrm{L}^{-1}$ and biomass-specific $\mathrm{NO}_{3}$ uptake rates accelerate resulting in a rapidly developing bloom nourished by $\mathrm{NO}_{3}$. However, if residence time is too low to allow the phytoplankton to assimilate the inflowing $\mathrm{NH}_{4}$, as may happen with high river flow conditions or if there is very elevated $\mathrm{NH}_{4}$ inflow, the production processes are only $\mathrm{NH}_{4}$-based. $\mathrm{NO}_{3}$ is unused and exported from the ecosystem (i.e. to the Pacific Ocean). Reduced primary production is a counter-intuitive result of elevated $\mathrm{NH}_{4}$; the $\mathrm{NH}_{4}$ paradox.

Here, we focus on a change in the chronically elevated $\mathrm{NH}_{4}$ as a potential trigger for blooms in northern SFE; and those factors that may decrease the $\mathrm{NH}_{4}$ concentration. A weekly sampling program was conducted during spring 2010 allowing a detailed examination to be made of the conditions that enabled the spring bloom to develop. The data are interpreted with respect to a conceptual model describing how $\mathrm{NH}_{4}$ discharge from the SRWTP and flow in the Sacramento River may modulate nutrient conditions in Suisun Bay to allow a phytoplankton bloom (as occurred in 2000 and 2010) or to prevent blooms as in other years. These results contribute toward an understanding of the role of elevated anthropogenic $\mathrm{NH}_{4}$ in estuarine primary productivity such that similar ecosystems with low productivity related to elevated $\mathrm{NH}_{4}$ discharge could be successfully managed.

\section{Conceptual model of nutrients, river flow and phytoplankton in Suisun Bay: criteria for phytoplankton blooms}

\subsection{Box model}

A simple input/output model for Suisun Bay (herein "Bay") based on the sequence of bloom events described by Dugdale et al. (2007) was used to establish three criteria to evaluate when conditions are favorable for phytoplankton blooms. Fundamentally, the initial phytoplankton population must be capable of assimilating and controlling $\mathrm{NH}_{4}$ input to the Bay so that $\mathrm{NH}_{4}$ concentrations can be reduced sufficiently to enable $\mathrm{NO}_{3}$ uptake. The critical variables of the $\mathrm{NH}_{4}$ input are loading and concentration. 1) Loading to the Bay must not exceed the capacity of the phytoplankton to assimilate inflowing $\mathrm{NH}_{4}$ (Loading Criterion) otherwise $\mathrm{NH}_{4}$ concentrations within the Bay will increase. 2) The $\mathrm{NH}_{4}$ concentration in the Bay must be $\leq 4 \mu \mathrm{mol} \mathrm{L}^{-1}$ or if the incoming concentration is $>4 \mu \mathrm{mol} \mathrm{L}^{-1}$ then water residence time must be sufficient for the phytoplankton to reduce the concentration to $<4 \mu \mathrm{mol} \mathrm{L}^{-1}$ (Concentration Criterion). 3) To avoid washout of the phytoplankton from the Bay before they can accumulate, the dilution rate of the Bay must not exceed the growth rate of the phytoplankton (Washout Criterion). If any of the criteria are not met, blooms will not form and the ecosystem will remain in a low productivity mode based solely on $\mathrm{NH}_{4}$ uptake.

The variables needed to evaluate these criteria are $\mathrm{NH}_{4}$ input to the river, river flow, and $\mathrm{NH}_{4}$ uptake by the phytoplankton. From these variables, the parameters: loading, concentration, residence time and washout flow can be obtained by considering Suisun Bay as a box with surface area $(A)$ of $1.7 \times 10^{8} \mathrm{~m}^{2}$ and volume $(V)$ of $9.9 \times 10^{8} \mathrm{~m}^{3}$ with inflow from the Sacramento River that contains $\mathrm{NH}_{4}$ from the SRWTP and outflow toward Suisun Bay and the northern SFE. River flow rates $(F)$ were obtained from California Department of Water Resources Dayflow algorithm ("Delta Outflow" - www.water.ca.gov/dayflow/). Effluent $\mathrm{NH}_{4}$ concentrations and effluent flow rate were obtained from SRWTP (SRWTP pers. comm.). First, the $\mathrm{NH}_{4}$ input (discharge) as metric tons $\mathrm{N} \mathrm{d}^{-1}$ or mmol $\mathrm{N} \mathrm{d}^{-1}$ at the SRWTP $\left(\mathrm{NH}_{4}\right.$ input $\left._{\text {(SRWTP) }}\right)$ is calculated from the $\mathrm{NH}_{4}$ concentration in the effluent multiplied by the effluent flow.

$\mathrm{NH}_{4}$ input $_{(\mathrm{SRWTP})}=\left[\mathrm{NH}_{4}\right]_{\text {effluent }}$ effluent flow

Then the $\mathrm{NH}_{4}$ input at the SRWTP (in mmol N d $\mathrm{d}^{-1}$ ) divided by the area of Suisun Bay $(A)$ provides an estimate of the potential loading to the Bay:

Potential loading to Suisun Bay $\left(\mathrm{mmol} \mathrm{N} \mathrm{m}^{-2} \mathrm{~d}^{-1}\right)$

$=\mathrm{NH}_{4}$ input $_{(\mathrm{SRWTP})} / A$

The realized loading will be lower than the potential loading due to in situ changes in the Sacramento River during its transit from SRWTP to Suisun Bay, e.g. by nitrification and phytoplankton uptake (Parker et al., 2012c). $\mathrm{NH}_{4}$ concentrations decline downstream and $\mathrm{NO}_{2}$ and $\mathrm{NO}_{3}$ concentrations increase (e.g. Parker et al., 2012c), an indication of nitrification (Hager and Schemel, 1996). The $\mathrm{NH}_{4}$ was observed to decrease downstream by 75\% (Foe et al., 2010; Parker et al., 2012c; their Table 1) and this change must be applied to calculate realized loadings to Suisun Bay. Measurements of phytoplankton $\mathrm{NH}_{4}$ uptake $\left(4.65 \mathrm{mmol} \mathrm{N} \mathrm{m}{ }^{-2} \mathrm{~d}^{-1}\right)$ using ${ }^{15} \mathrm{~N}-\mathrm{NH}_{4}$ and estimates of microbial nitrification (32.0-51.2 mmol N m${ }^{-2} \mathrm{~d}^{-1}$ ) indicated that the downstream decrease in $\mathrm{NH}_{4}$ was due mostly to nitrification (Parker et al., 2012c). The nitrification rates were obtained using both a mass balance approach from increasing $\mathrm{NO}_{3}$ concentrations downstream between SRWTP and Suisun Bay along with travel time, and also using an average specific nitrification factor (Yool et al., 2007) to predict the $\mathrm{NO}_{3}$ produced from the ambient $\mathrm{NH}_{4}$ in the river.

The directly estimated loading to Suisun Bay can also be obtained by calculating the $\mathrm{NH}_{4}$ input to the Bay from the measured $\mathrm{NH}_{4}$ concentration of the water entering the Bay multiplied by the flow into the Bay.

$\mathrm{NH}_{4}$ input $_{(\text {Suisun })}=\left[\mathrm{NH}_{4}\right]_{\text {Suisun }}{ }^{*} \mathrm{~F}$

And then:

Directly estimated loading to Suisun Bay $\left(\mathrm{mmol} \mathrm{N} \mathrm{m}{ }^{-2} \mathrm{~d}^{-1}\right)$

$=\mathrm{NH}_{4}$ input $_{(\text {Suisun })} / A$

Table 1

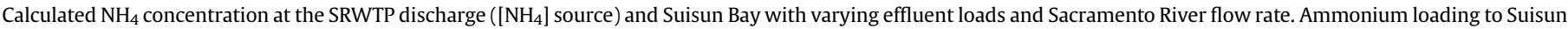
Bay is calculated with and without $\mathrm{NH}_{4}$ loss (due to nitrification).

\begin{tabular}{|c|c|c|c|c|c|}
\hline \multirow{2}{*}{$\begin{array}{l}\text { SRWTP effluent } \\
\text { load tons } \mathrm{NH}_{4}-\mathrm{N} \mathrm{d}^{-1}\end{array}$} & \multirow{2}{*}{$\begin{array}{l}\text { Flow rate } \\
\mathrm{m}^{3} \mathrm{~s}^{-1}\end{array}$} & \multirow{2}{*}{$\begin{array}{l}{\left[\mathrm{NH}_{4}\right] \text { source at }} \\
\text { SRWTP } \mu \mathrm{mol} \mathrm{L}^{-1}\end{array}$} & \multirow{2}{*}{$\begin{array}{l}\mathrm{NH}_{4} \text { inflow at } \\
\text { Suisun Bay } \mu \mathrm{mol} \mathrm{L}{ }^{-1}\end{array}$} & \multicolumn{2}{|c|}{ Loading to Suisun Bay mmol m${ }^{-2} \mathrm{~d}^{-1}$} \\
\hline & & & & Potential with no nitrification & Realized with nitrification \\
\hline 5 & 500 & 8.27 & 2.07 & 2.11 & 0.53 \\
\hline 5 & 1000 & 4.13 & 1.03 & 2.11 & 0.53 \\
\hline 5 & 2000 & 2.07 & 0.52 & 2.11 & 0.53 \\
\hline 10 & 500 & 16.63 & 4.13 & 4.21 & 1.05 \\
\hline 10 & 1000 & 8.27 & 2.07 & 4.21 & 1.05 \\
\hline 10 & 2000 & 4.13 & 1.03 & 4.21 & 1.05 \\
\hline 15 & 500 & 24.80 & 6.20 & 6.32 & 1.58 \\
\hline 15 & 1000 & 12.40 & 3.10 & 6.32 & 1.58 \\
\hline 15 & 2000 & 6.20 & 1.60 & 6.32 & 1.58 \\
\hline
\end{tabular}


The $\mathrm{NH}_{4}$ concentration (in $\mu \mathrm{mol} \mathrm{L} \mathrm{L}^{-1}=\mathrm{mmol} \mathrm{m}^{-3}$ ) at the entrance to Suisun Bay ( $\left[\mathrm{NH}_{4}\right]_{(\text {Susiun) }}$ ) can be calculated using the $\mathrm{NH}_{4}$ discharge at SRWTP and river flow $(F)$ to calculate concentration at the source of discharge $\left(\left[\mathrm{NH}_{4}\right]\right.$ source $\left._{(\mathrm{SRWTP})}\right)$ that is then multiplied by 0.25 to allow for the $75 \%$ decrease in $\mathrm{NH}_{4}$ downriver due to microbial nitrification (see Section 2.1 for rationale):

$$
\begin{aligned}
{\left[\mathrm{NH}_{4}\right]_{(\text {Susiun })} } & =\left[\mathrm{NH}_{4}\right] \text { source }(\mathrm{SRWTP}) * 0.25 \\
& =\left(\mathrm{NH}_{4} \operatorname{input}(\mathrm{SRWTP}) / F\right) * 0.25
\end{aligned}
$$

To estimate the maximum river flow $\left(F_{\max }\right)$ allowed before dilution $(D)$ results in no net phytoplankton growth for the Washout Criterion, Suisun Bay dilution is calculated as:

$D\left(\right.$ as time $\left.^{-1}\right)=F / V$

where $F$ is river flow and $V$ is volume of Suisun Bay $\left(9.9 \times 10^{8} \mathrm{~m}^{3} \mathrm{~s}^{-1}\right)$. Then:

$F=D^{*} V$

From chemostat analogy, dilution $(D)$ cannot be greater than phytoplankton growth rate - in this case the mean phytoplankton biomass-specific $\mathrm{NH}_{4}$ uptake rate $\left(\mathrm{VNH}_{4}\right.$, time $\left.{ }^{-1}\right)$.

So the washout point $D_{\max }=V N_{4}$

From Eqn. (7)

$F_{\max }=D_{\max } * V=V \mathrm{NH}_{4} * V=V \mathrm{NH}_{4} * 9.9 \times 10^{8} \mathrm{~m}^{3} \mathrm{~s}^{-1}$

At this flow and greater, there is no net growth of phytoplankton in the Bay, and the concentration of inflowing and outflowing phytoplankton biomass will be the same.

The interrelationships between $\mathrm{NH}_{4}$ discharge, $\mathrm{NH}_{4}$ concentration and river flow are shown as three hyperbolae (Fig. 2) calculated for discharges at the SRWTP of 15,10 and 5 metric tons $\mathrm{NH}_{4}-\mathrm{N} \mathrm{d}^{-1}$ from Eqn. (5) relating river flow and $\mathrm{NH}_{4}$ concentration. At any given river flow, the $\mathrm{NH}_{4}$ concentration at the entrance to Suisun Bay increases as discharge increases (Eqn. (5)). The intersection of the solid horizontal line drawn from the $\mathrm{NH}_{4}=4 \mu \mathrm{mol} \mathrm{L}{ }^{-1}$ with a discharge hyperbola indicates the minimum flow needed to dilute $\mathrm{NH}_{4}$ concentration to $4 \mu \mathrm{mol} \mathrm{L}^{-1}$ (the Concentration Criterion). The washout threshold flow $\left(F_{\max }\right)$ is shown as the right-hand vertical dashed line on Fig. 2 . The range of river flows within which bloom initiation can occur is set by this upper limit and a lower flow set by the discharge (vertical dotted lines). The window of flow rates contracts as the discharge increases, shown by the dotted vertical lines.

\subsection{Calculating $\mathrm{NH}_{4}$ loadings and concentrations}

Using $\mathrm{NH}_{4}$ discharges at SRWTP of 5, 10 and 15 tons $\mathrm{NH}_{4}-\mathrm{N} \mathrm{d}^{-1}$ (bracketing 1987 to present-day $\mathrm{NH}_{4}-\mathrm{N}$ discharges, Jassby, 2008) and Eqn. (2), the potential area-based loading of $\mathrm{NH}_{4}$ to Suisun Bay from the Sacramento River increased from 2.11 to $6.32 \mathrm{mmol} \mathrm{m}^{-2} \mathrm{~d}^{-1}$ over that period (Table 1 ). A reduction of $75 \%$ is applied to the discharge at SRWTP, to give realized (nitrificationcorrected, see Section 2.1) area-based $\mathrm{NH}_{4}$ loadings to Suisun Bay of 0.53 (when there was 5 tons $\mathrm{NH}_{4}-\mathrm{N} \mathrm{d}^{-1}$ discharge at SRWTP), to $1.58 \mathrm{mmol} \mathrm{m}^{-2} \mathrm{~d}^{-1}$ at 15 tons $\mathrm{NH}_{4}-\mathrm{N} \mathrm{d}^{-1}$ (present-day).

Three flow rates $\left(500,1000\right.$, and $2000 \mathrm{~m}^{3} \mathrm{~s}^{-1}$ ) and three $\mathrm{NH}_{4}$ inputs at $\operatorname{SRWTP}\left(5,10\right.$ and 15 tons $\left.\mathrm{NH}_{4}-\mathrm{N} \mathrm{d}^{-1}\right)$ were used to calculate $\mathrm{NH}_{4}$ concentration at the SRWTP discharge point and then at the entrance to Suisun Bay applying the $75 \%$ reduction due to nitrification (Table 1, Eqn. (5)). Ammonium concentrations at a given flow rate increase as the discharge rate increases. This analysis does not include when the flow into Suisun Bay is not equal to the flow at the SRWTP which occurs when water is diverted from

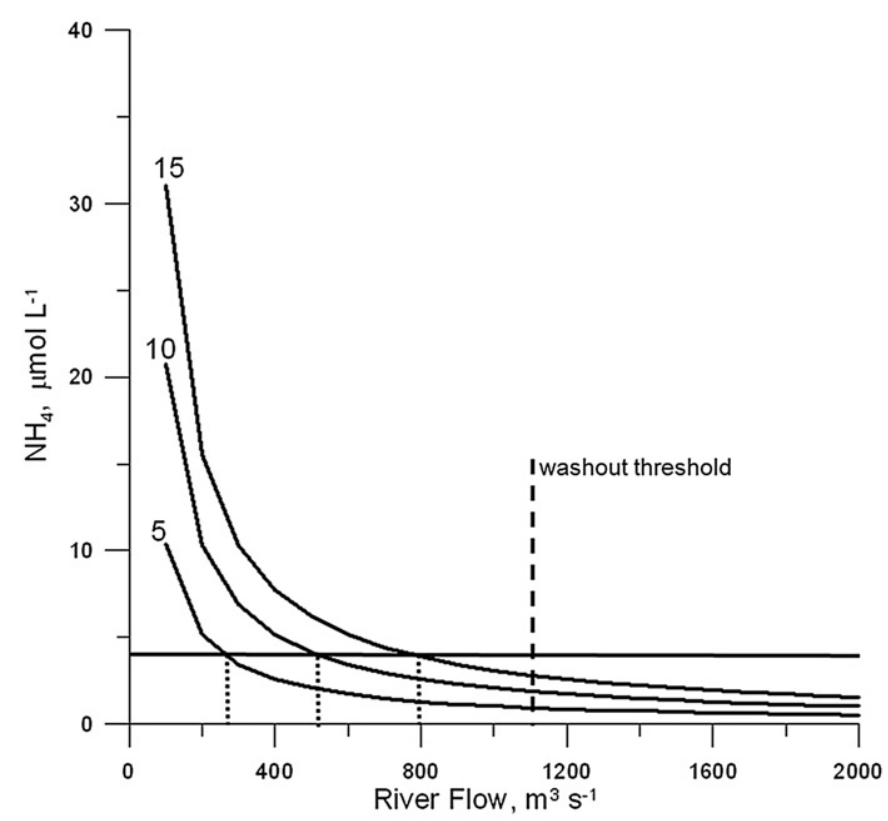

Fig. 2. Ammonium concentration of inflowing river water at the entrance to Suisun Bay as a function of river flow at point of discharge and three effluent discharge levels (5. 10 and 15 tons $\mathrm{NH}_{4}-\mathrm{N} \mathrm{d}^{-1}$ ). The 3 dotted vertical lines show the river flow that will result in $\mathrm{NH}_{4}=4 \mu \mathrm{mol} \mathrm{L}^{-1}$ at Suisun Bay for each of three discharge levels. The dashed vertical line shows the washout criterion at which the phytoplankton population washes out

the Sacramento for agricultural and domestic use. Also, additional sources of $\mathrm{NH}_{4}$ (e.g. other WTPs) were not included in these calculated loadings as it is assumed here that SRWTP represents the only $\mathrm{NH}_{4}$ source to Suisun Bay. It has been shown that SRWTP as a point source supplies $90 \%$ of the $\mathrm{NH}_{4}$ (Jassby, 2008) in the northern SFE. Present-day nutrient inventories for the Sacramento River and Suisun Bay are incomplete but Hager and Schemel (1992) suggest that agricultural sources are minor downstream of the SRWTP and the location of nonpoint source of nutrients is unclear and likely to have insignificant inputs.

\subsection{Obtaining values for the three criteria}

\subsubsection{Loading Criterion}

To evaluate the Loading Criterion (i.e. that $\mathrm{NH}_{4}$ loading must not exceed the $\mathrm{NH}_{4}$ uptake capacity of the phytoplankton), peak and non-peak phytoplankton $\mathrm{NH}_{4}$ uptake rates were used to evaluate whether Suisun Bay phytoplankton have the capacity to keep pace with potential $\mathrm{NH}_{4}$ loading. The mean phytoplankton $\mathrm{NH}_{4}$ uptake during spring in Suisun Bay measured from 1999 to 2003 was $0.032 \mathrm{mmol} \mathrm{m}^{-3} \mathrm{~h}^{-1}$ (Wilkerson et al., 2006) and the peak value was $0.074 \mathrm{mmol} \mathrm{m} \mathrm{m}^{-3} \mathrm{~h}^{-1}$ (unpublished data). These hourly rates were converted to daily rates $\left({ }^{*} 24\right)$ and then depth-integrated values were obtained $\left(0.88 \mathrm{mmol} \mathrm{m}^{-2} \mathrm{~d}^{-1}\right.$ and $\left.2.02 \mathrm{mmol} \mathrm{m}^{-2} \mathrm{~d}^{-1}\right)$ assuming uniform uptake throughout the euphotic zone and estimating euphotic zone from the mean spring Secchi depth measured in Suisun of $0.3 \mathrm{~m}$ (Wilkerson et al., 2006) using the relationship in Cole and Cloern (1987). Comparison of the historical $\mathrm{NH}_{4}$ discharges to Suisun Bay with the mean and peak phytoplankton $\mathrm{NH}_{4}$ uptake rates $\left(0.88 \mathrm{mmol} \mathrm{m}^{-2} \mathrm{~d}^{-1}\right.$ and $\left.2.02 \mathrm{mmol} \mathrm{m}^{-2} \mathrm{~d}^{-1}\right)$ indicates that the discharge of 10 tons $\mathrm{NH}_{4}-\mathrm{N} \mathrm{d}^{-1}$ and the current 15 tons $\mathrm{NH}_{4}-\mathrm{N} \mathrm{d}^{-1}$ exceed the mean capacity of the Suisun Bay phytoplankton to absorb the input of $\mathrm{NH}_{4}$ (Table 1). With discharge of 15 tons $\mathrm{NH}_{4}-\mathrm{N} \mathrm{d}^{-1}$ phytoplankton uptake rate must exceed $1.58 \mathrm{mmol} \mathrm{m}^{-2} \mathrm{~d}^{-1}$ (Table 1). In order to change the balance in favor of phytoplankton 
bloom formation, either $\mathrm{NH}_{4}$ loading would need to decrease or the phytoplankton $\mathrm{NH}_{4}$ uptake rate would need to increase (to the peak value). At the 5 tons $\mathrm{NH}_{4}-\mathrm{N} \mathrm{d}^{-1}$ discharge in 1987, the phytoplankton uptake would have been capable of absorbing the $\mathrm{NH}_{4}$ input.

\subsubsection{Concentration Criterion}

The second criterion (Concentration Criterion) for rapid $\mathrm{NO}_{3}-$ based bloom initiation requires an $\mathrm{NH}_{4}$ concentration of $\leq 4 \mu \mathrm{mol} \mathrm{L}{ }^{-1}$. The concentrations calculated for Suisun Bay (allowing for $75 \%$ reduction between the SWRTP and Suisun Bay due mostly to nitrification-see Section 2.1) (Table 1) suggest that this criterion is met at present-day discharge at flows of 1000 and $2000 \mathrm{~m}^{3} \mathrm{~s}^{-1}$. At $500 \mathrm{~m}^{3} \mathrm{~s}^{-1}$, the calculated inflowing $\mathrm{NH}_{4}$ concentration is $6.2 \mu \mathrm{mol} \mathrm{L}^{-1}$, in excess of the required $4 \mu \mathrm{mol} \mathrm{L}^{-1}$. In Fig. 2, a line drawn from the $y$-axis at a concentration of $4 \mu \mathrm{mol} \mathrm{L}^{-1}$ is the upper boundary for the Concentration Criterion. The intersection of that line with a discharge hyperbola indicates the minimum flow required to meet the Concentration Criterion indicated by the vertical line intersecting the $x$-axis. As discharge increases, the necessary river flow increases. At the present discharge, 15 tons $\mathrm{NH}_{4}-\mathrm{N} \mathrm{d}^{-1}$, flow of at least $800 \mathrm{~m}^{3} \mathrm{~s}^{-1}$ is required.

\subsubsection{Washout Criterion}

The washout threshold flow $\left(F_{\max }\right)$, shown as the right-hand vertical dashed line on Fig. 2 , is based on the mean biomass-specific $\mathrm{NH}_{4}$ uptake rate for Suisun Bay in spring, $0.004 \mathrm{~h}^{-1}$ (Wilkerson et al., 2006). From Eqn. (8)

$F_{\max }=0.004 \mathrm{~h}^{-1} * 9.9 \times 10^{8} \mathrm{~m}^{3}=1100 \mathrm{~m}^{3} \mathrm{~s}^{-1}$

The range of river flows within which bloom initiation can occur is set by this upper limit and a lower flow set by the discharge. The window of flow rates contracts as the discharge increases and at present discharge ( 15 metric tons $\mathrm{NH}_{4}-\mathrm{N} \mathrm{d}^{-1}$ ) is relatively narrow (i.e. $800-1100 \mathrm{~m}^{3} \mathrm{~s}^{-1}$ ).

In summary, for bloom initiation, besides sufficient irradiance, if the discharge at SRWTP is the present day value of 15 tons $\mathrm{NH}_{4}-$ $\mathrm{N} \mathrm{d}^{-1}$, Criterion 1 (Loading Criterion) requires that the phytoplankton $\mathrm{NH}_{4}$ uptake rate must exceed $1.58 \mathrm{mmol} \mathrm{m}^{-2} \mathrm{~d}^{-1}$; Criterion 2 (Concentration Criterion, $\mathrm{NH}_{4}=\sim 4 \mu \mathrm{mol} \mathrm{L}^{-1}$ at Suisun Bay) requires river flow $>800 \mathrm{~m}^{3} \mathrm{~s}^{-1}$ at the SRWTP for sufficient dilution and Criterion 3 (Washout Criterion) requires river flow at Suisun Bay $<1100 \mathrm{~m}^{2} \mathrm{~s}^{-1}$. The river flow, discharge and loading conditions during spring 2010 were evaluated to establish if any of these criteria were met to allow bloom initiation.

\section{Site description and methods}

Seven stations were sampled in the main channel $(\sim 10 \mathrm{~m}$ depth) of Suisun Bay along with a single shoal station ( $<2$ m depth: DWR-D7), on 17, 24 March; 7, 14, 26 April; 12, 24 May and 16, 21 June 2010 (Fig. 1). At each station measurements of water transparency were made with a Secchi disk, and temperature and salinity with a YSI-6920 sonde. Salinity was measured using the Practical Salinity Scale. Surface water was sampled with a clean bucket for concentrations of nutrients and chlorophyll as well as enumeration of phytoplankton species.

The sampled water was filtered through clean precombusted (450 ${ }^{\circ} \mathrm{C}$, 4-hr) $25 \mathrm{~mm}$ Whatman $\mathrm{GF} / \mathrm{F}$ filters and the filtrate collected for nutrient analyses. Twenty-ml filtered samples were analyzed using a Bran and Luebbe AutoAnalyzer II with MT-19 manifold chemistry module for $\mathrm{NO}_{3}+\mathrm{NO}_{2}$ and $\mathrm{NO}_{2}$ according to Whitledge et al. (1981) and Bran and Luebbe Method G-172-96 (Bran Luebbe, 1999a), phosphate $\left(\mathrm{PO}_{4}\right)$ according to Bran and
Luebbe Method G-175-96 (Bran Luebbe, 1999b) and silicate $\left(\mathrm{Si}(\mathrm{OH})_{4}\right)$ by Bran and Luebbe Method G-177-96 (Bran Luebbe, 1999c). $\mathrm{NO}_{3}+\mathrm{NO}_{2}$ is referred to as $\mathrm{NO}_{3}$ throughout the text as $\mathrm{NO}_{2}$ concentrations were very low $\left(<1.0 \mu \mathrm{mol} \mathrm{L}^{-1}\right)$. Twenty-five $\mathrm{ml}$ filtered samples were analyzed for $\mathrm{NH}_{4}$ according to Solorzano (1969). Samples for chlorophyll were prepared in the field by filtering $50 \mathrm{mls}$ of sample water onto $25 \mathrm{~mm}$ Whatman GF/F filters. Chlorophyll on the filters was determined by in vitro fluorometry after extraction in $90 \%$ acetone using a Turner 10AU fluorometer (Arar and Collins, 1992) calibrated with commercially available chlorophyll (Turner Designs) and corrected for phaeophytin by hydrochloric acid addition (Holm-Hansen et al., 1965). Water was sampled in 250-ml amber glass bottles and preserved with Lugols iodine for phytoplankton enumeration, using the Utermohl settling technique (Utermohl, 1958) with 25-ml chambers and inverted microscopy. Phytoplankton were identified to genus. Laboratory quality assurance/quality control followed the Surface Water Ambient Monitoring Program (SWAMP) protocols set by the California State Water Resources Control Board (http://www. waterboards.ca.gov/water_issues/programs/swamp/qamp.shtml). This included implementation of standard laboratory procedures including replicates, field blanks, matrix spikes, certified reference materials, setting of control limits, criteria for rejection, and data validation methods. All analyses were carried out on fresh samples within $24 \mathrm{~h}$ of collection.

\section{Results}

\subsection{Field observations of chlorophyll, nutrients and phytoplankton}

When sampling began on 17 March, 2010, $\mathrm{NH}_{4}$ concentrations were high, $\left(6.8-10.3 \mu \mathrm{mol} \mathrm{L}^{-1}\right)$ with the maximum value at the most upstream location, at the entrance to Suisun Bay, DWR-D4 (Figs. 1 and 3a) and chlorophyll concentrations were uniformly low (1.4-3.4 $\left.\mu \mathrm{g} \mathrm{L}^{-1}\right)$. By 24 March, chlorophyll concentrations increased $\left(2.8-4.3 \mu \mathrm{g} \mathrm{L}^{-1}\right)$ and $\mathrm{NH}_{4}$ concentrations were relatively unchanged (Fig. 3b) except for DWR-D4 where $\mathrm{NH}_{4}$ had declined substantially. Two weeks later, 7 April, chlorophyll concentrations had increased (3.7-7.4 $\left.\mu \mathrm{g} \mathrm{L}^{-1}\right)$ at all but the two most downstream stations (Fig. 3c). $\mathrm{NH}_{4}$ concentrations had declined at all stations except DWR-D4. The lowest $\mathrm{NH}_{4}$ concentrations were found at the mid Suisun Bay stations, USGS 5 and USGS 6 (4.4 and $3.7 \mu \mathrm{mol} \mathrm{L} \mathrm{L}^{-1}$, respectively) and the shoal station DWR-D7 (3.4 $\mu \mathrm{mol} \mathrm{L}{ }^{-1}$ ). Station DWR-D4 had elevated $\mathrm{NH}_{4}$ compared to the other stations.

One week later, 14 April, a phytoplankton bloom was observed in mid Suisun Bay (USGS 5) with a chlorophyll concentration of $30.9 \mu \mathrm{g} \mathrm{L}^{-1}$. $\mathrm{NH}_{4}$ concentrations at this station were $1.7 \mu \mathrm{mol} \mathrm{L}^{-1}$ (Fig. 3d) and were consistently low across stations in mid Suisun Bay. The highest $\mathrm{NH}_{4}$ concentration $\left(8.6 \mu \mathrm{mol} \mathrm{L}{ }^{-1}\right)$ occurred at USGS 7, located in western Suisun Bay adjacent to the Central Contra Costa Sanitation District WTP outfall. Chlorophyll concentrations were low $\left(1.9 \mu \mathrm{g} \mathrm{L}^{-1}\right.$ and $\left.1.5 \mu \mathrm{g} \mathrm{L}^{-1}\right)$ at USGS 7 and the next downstream station, USGS 8.

On 26 April, there was a clear U-shaped pattern of $\mathrm{NH}_{4}$ concentration within Suisun Bay with a minimum at USGS 5 (Fig. 3e). A mirror image pattern of chlorophyll was also observed (Fig. 3e) with the lowest chlorophyll upstream and downstream and the maxima at USGS $5\left(21 \mu \mathrm{g} \mathrm{L}^{-1}\right)$ and the shoal station (DWRD7, $\left.20 \mu \mathrm{g} \mathrm{L}^{-1}\right)$. By May 12, the bloom had largely faded although substantial chlorophyll concentrations $\left(5-10 \mu \mathrm{g} \mathrm{L}^{-1}\right)$ still remained at all but the two downstream stations where the highest $\mathrm{NH}_{4}$ concentrations (5.2 and $7.2 \mu \mathrm{mol} \mathrm{L}{ }^{-1}$ ) were measured (Fig. 3f).

Two weeks later, 24 May, a second, larger phytoplankton bloom both in magnitude and spatial extent had developed, with 


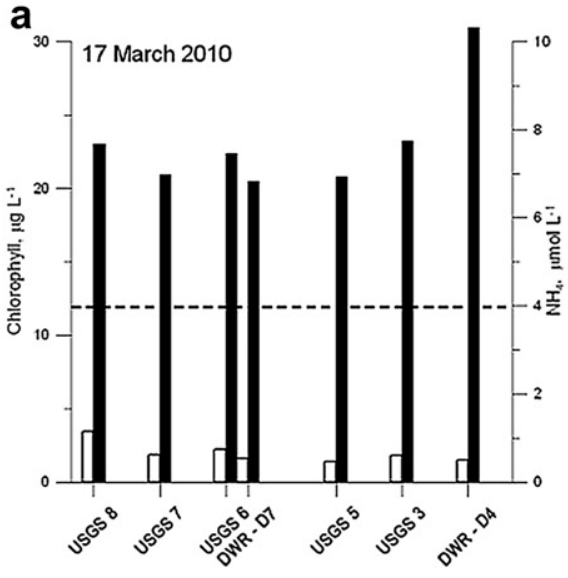

d
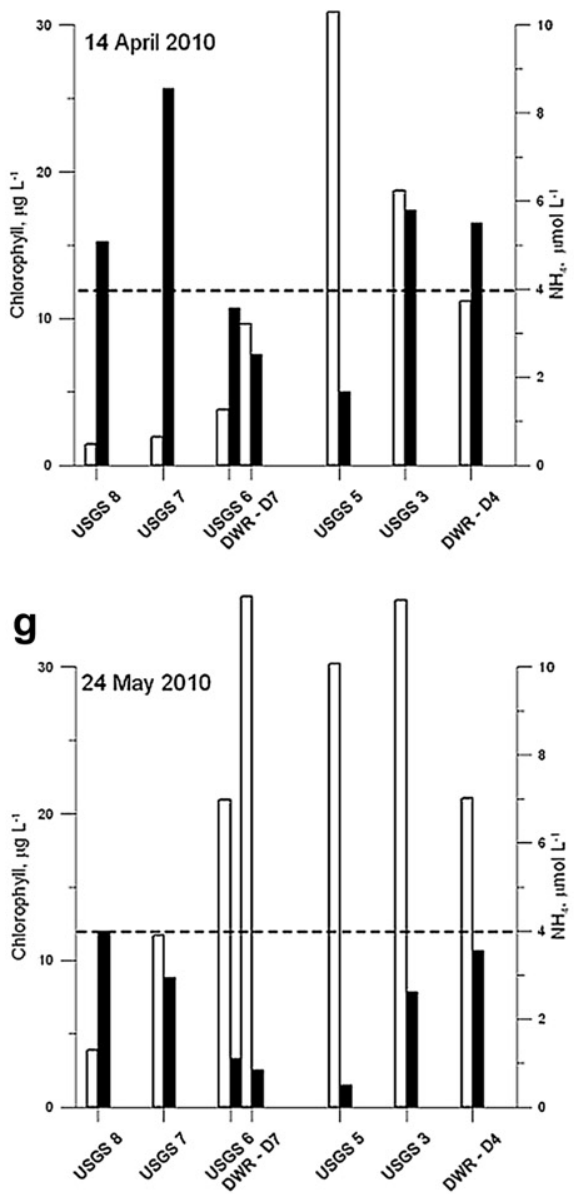

b

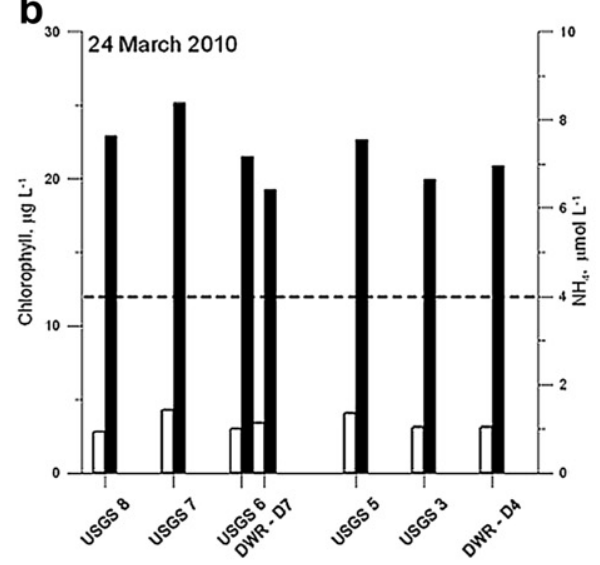

e

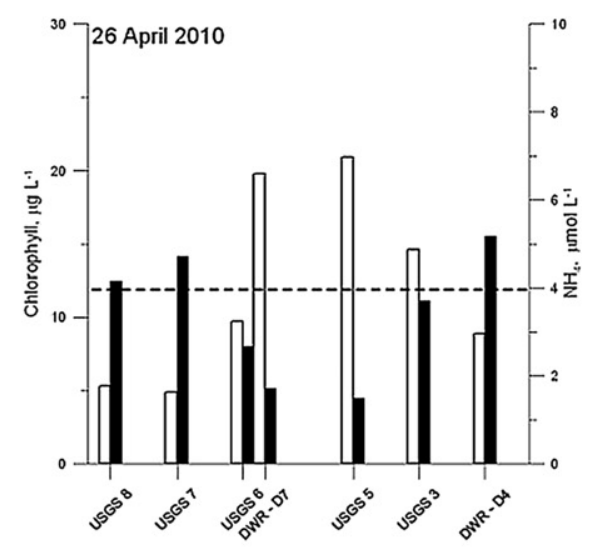

h

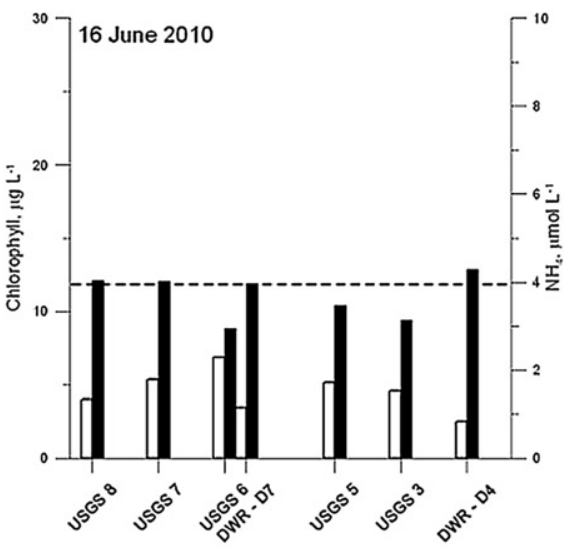

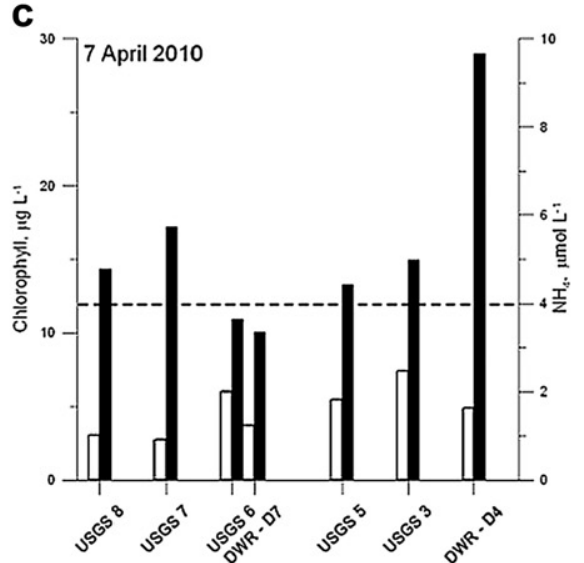

f

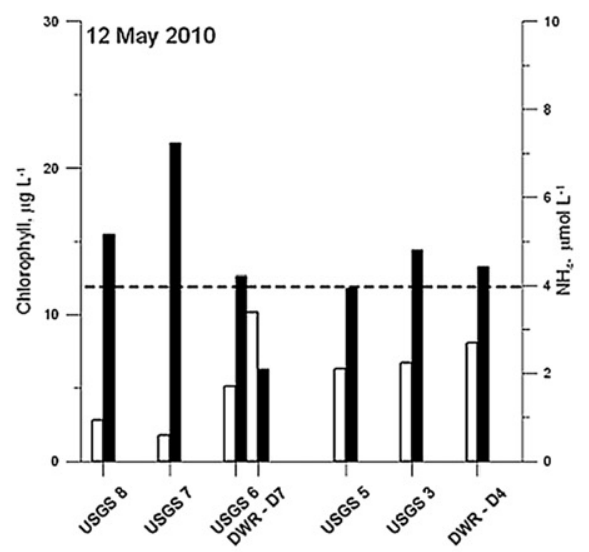

i

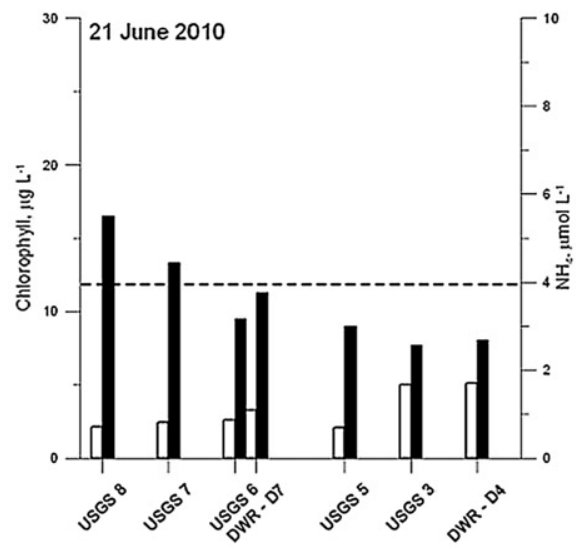

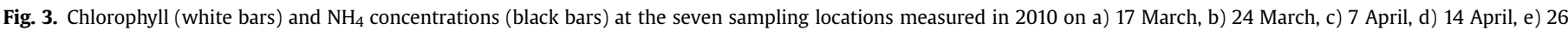

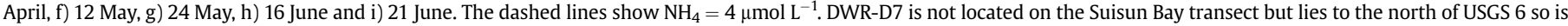
plotted next to USGS 6.

chlorophyll up to $34 \mu \mathrm{g} \mathrm{L}^{-1}$ at all but the two downstream stations, USGS 7 and USGS 8 (Fig. $3 \mathrm{~g}$ ). Ammonium concentrations were $\leq 1 \mu \mathrm{mol} \mathrm{L^{-1 }}$ at mid-Bay stations including DWR-D7, and $<4 \mu \mathrm{mol} \mathrm{L}{ }^{-1}$ at the most upstream station (DWR-D4). By 16 June, chlorophyll had declined to between 2.5 and $6.9 \mu \mathrm{g} \mathrm{L}^{-1}$ within the study area and $\mathrm{NH}_{4}$ concentrations were $\sim 4 \mu \mathrm{mol} \mathrm{L}{ }^{-1}$ (Fig. 3h). One week later, 21 June, chlorophyll concentrations had declined further $\left(2-5 \mu \mathrm{g} \mathrm{L}^{-1}\right)$ and a pattern of $\mathrm{NH}_{4}$ concentration (2.5$5.5 \mu \mathrm{mol} \mathrm{L}{ }^{-1}$ ) increasing downstream was apparent (Fig. 3i).
The spatial and temporal patterns in chlorophyll and $\mathrm{NH}_{4}$, along with $\mathrm{NO}_{3}, \mathrm{Si}(\mathrm{OH})_{4}$ and $\mathrm{PO}_{4}$ are shown also as contours on a location (DWR-D4 in Suisun Bay to USGS 8 near San Pablo Bay) versus time plane in Fig. 4a-e. The two blooms (end of April and May) were centered at USGS 3 to USGS 5 (Fig. 4a). These blooms occurred on the upstream side of the 2 isohaline (Fig. 4a). $\mathrm{NH}_{4}$ concentration (Fig. 4b) declined through mid-Bay but increased again at USGS 7, with an $\mathrm{NH}_{4}$ minimum $\left(<4 \mu \mathrm{mol} \mathrm{L}^{-1}\right)$ corresponding closely to the chlorophyll maximum distribution with time. $\mathrm{NO}_{3}$ concentrations 
(Fig. 4c) declined with time from about 35 to $10 \mu \mathrm{mol} \mathrm{L}^{-1}$, the latter coincident with the second bloom. Phosphate and $\mathrm{Si}(\mathrm{OH})_{4}$ concentrations declined as spring progressed with lower values observed during the periods of both blooms (Fig. 4d, e). A Si $(\mathrm{OH})_{4}$ minimum was associated with the second bloom. At DWR-D4 the Secchi depth varied little with a mean of $0.6 \pm 0.2 \mathrm{~m}$ and the mean salinity was low, $0.14 \pm 0.07$ (Table 2).

Diatoms made up virtually all of the phytoplankton counted (Fig. 5). The abundances of the five most common diatoms at three channel stations, DWR-D4, USGS 3, USGS 5 and at the shoal station, DWR-D7 are plotted for five sampling dates in 2010; 24 March, 7, 14 and 26 April and 24 May (Fig. 5). The first bloom in April (Fig. 5c) was dominated by the pennate diatom Entomoneis (synonym: Amphiprora; http://westerndiatoms.colorado.edu) and the second on 24 May (Fig. 5e) by the long-chain centric diatom Melosira Fig. 5a-d). Entomoneis (a tychopelagic diatom that is normally benthic; Cupp, 1943) occurred persistently in the shoal and downstream region of Suisun Bay, while centric pelagic diatoms (Cyclotella and Melosira) were upstream (Fig. 5a-d). Diatom dominance in the two blooms is consistent with the concurrent decline in $\mathrm{Si}(\mathrm{OH})_{4}$ and increased chlorophyll (Fig. 4).

\section{2. $\mathrm{NH}_{4}$ loading to Suisun Bay, $\mathrm{NH}_{4}$ concentrations in Suisun Bay and river flow in spring 2010}

\subsubsection{Loading}

Discharge of $\mathrm{NH}_{4}$ at SRWTP (Fig. 6a) was calculated from effluent concentrations and effluent flow at the SRWTP and normalized to the surface area of Suisun Bay (Eqns. (1) and (2)). In the period 17 March to 7 April potential loading varied from 5.24$6.61 \mathrm{mmol} \mathrm{m}^{-2} \mathrm{~d}^{-1}$ (Table 2), then remained $\sim 6 \mathrm{mmol} \mathrm{m}^{-2} \mathrm{~d}^{-1}$ through 12 May and then declined to $5.59 \mathrm{mmol} \mathrm{m}^{-2} \mathrm{~d}^{-1}$ on 24 May. The mean $\mathrm{NH}_{4}$ loading for the period 17 March to 24 May, $5.86 \pm 0.52 \mathrm{mmol} \mathrm{m}^{-2} \mathrm{~d}^{-1}$ is not distinguishable from the loading with a discharge rate of 15 tons $\mathrm{NH}_{4}-\mathrm{N} \mathrm{d}^{-1}, 6.32 \mathrm{mmol} \mathrm{m}^{-2} \mathrm{~d}^{-1}$ (Table 1 ). When realized loading at the entrance to Suisun Bay was estimated by application of a $75 \%$ reduction due to nitrification (see section 2.1), the values (Table 2) fall within the range of the Loading
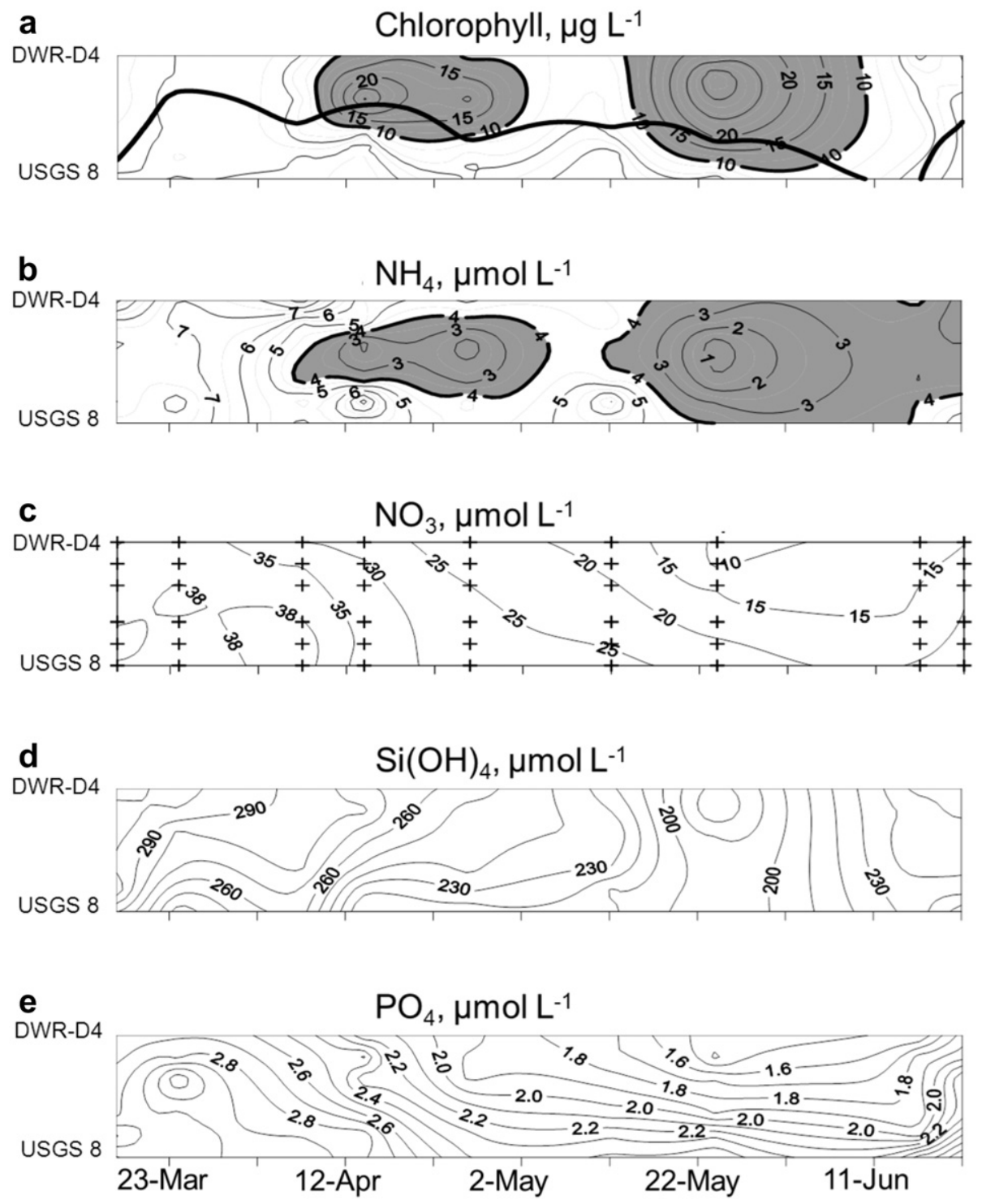

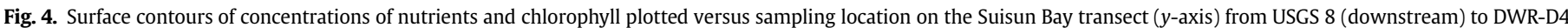

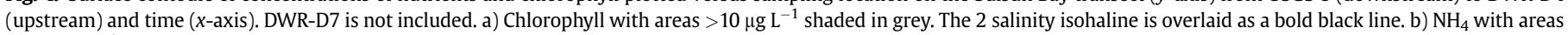
$<4 \mu \mathrm{mol} \mathrm{L}{ }^{-1}$ shaded in grey, c) $\mathrm{NO}_{3}$, d) $\mathrm{Si}(\mathrm{OH})_{4}$, e) $\mathrm{PO}_{4}$. Crosses on c) show the sampling locations. 
Table 2

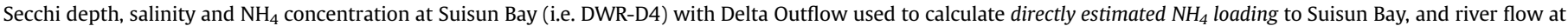

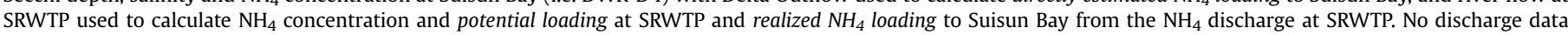
available for June 2010 , so no calculated values.

\begin{tabular}{|c|c|c|c|c|c|c|c|c|c|c|}
\hline Date 2010 & $\begin{array}{l}\text { Secchi } \\
\text { depth } \mathrm{m}\end{array}$ & Salinity & $\begin{array}{l}\text { Delta Outflow } \\
\mathrm{m}^{3} \mathrm{~s}^{-1}\end{array}$ & $\begin{array}{l}\text { Measured } \mathrm{NH}_{4} \\
\text { at Suisun } \\
\mu \mathrm{mol} \mathrm{L}\end{array}$ & $\begin{array}{l}\text { Directly estimated } \\
\mathrm{NH}_{4} \text { loading to } \\
\text { Suisun mmol } \\
\mathrm{m}^{-2} \mathrm{~d}^{-1}\end{array}$ & $\begin{array}{l}\text { Calc } \mathrm{NH}_{4} \text { at } \\
\text { Suisun } \\
\mu \mathrm{mol} \mathrm{L}^{-1}\end{array}$ & $\begin{array}{l}\text { Realized } \mathrm{NH}_{4} \\
\text { loading to } \\
\text { Suisun } \\
\text { mmol } \\
\mathrm{m}^{-2} \mathrm{~d}^{-1}\end{array}$ & $\begin{array}{l}\text { River flow } \\
\text { at SRWTP } \\
\mathrm{m}^{3} \mathrm{~s}^{-1}\end{array}$ & $\begin{array}{l}\text { Calc } \mathrm{NH}_{4} \text { at } \\
\text { SRWTP } \\
\mu \mathrm{mol} \mathrm{L}^{-1}\end{array}$ & $\begin{array}{l}\text { Potential } \mathrm{NH}_{4} \\
\text { loading at } \\
\text { SRWTP } \\
\text { mmol m}^{-2} \mathrm{~d}^{-1}\end{array}$ \\
\hline 17 March & 0.50 & 0.13 & 395.1 & 10.31 & 2.08 & 5.20 & 1.31 & 495.3 & 20.78 & 5.24 \\
\hline 24 March & 0.50 & 0.30 & 262.5 & 6.97 & 0.93 & 6.68 & 1.31 & 384.9 & 26.73 & 5.25 \\
\hline 7 April & 1.00 & 0.18 & 567.0 & 9.66 & 2.79 & 7.74 & 1.65 & 418.9 & 30.95 & 6.61 \\
\hline 14 April & 0.75 & 0.14 & 759.7 & 5.50 & 2.13 & 5.16 & 1.56 & 591.6 & 20.63 & 6.22 \\
\hline 26 April & 0.50 & 0.11 & 709.8 & 5.18 & 1.87 & 5.36 & 1.49 & 546.3 & 21.45 & 5.97 \\
\hline 12 May & 0.50 & 0.11 & 604.8 & 4.43 & 1.36 & 6.98 & 1.54 & 433.1 & 27.90 & 6.15 \\
\hline 24 May & 0.25 & 0.11 & 503.7 & 3.56 & 0.91 & 6.50 & 1.40 & 421.7 & 26.00 & 5.59 \\
\hline 16 June & 0.50 & 0.07 & & & & & & & & \\
\hline 21 June & 0.50 & 0.08 & & & & & & & & \\
\hline Mean \pm s.d. & $0.56 \pm 0.21$ & $0.14 \pm 0.07$ & $543.2 \pm 173.8$ & $6.52 \pm 2.59$ & $1.73 \pm 0.69$ & $6.23 \pm 1.01$ & $1.47 \pm 0.13$ & $470.3 \pm 76.1$ & $24.92 \pm 4.03$ & $5.86 \pm 0.52$ \\
\hline $\begin{array}{r}17 \mathrm{Mar}-7 \mathrm{Apr} \\
\text { mean } \pm \text { s.d. }\end{array}$ & $0.67 \pm 0.29$ & $0.20 \pm 0.09$ & $408.2 \pm 152.7$ & $8.98 \pm 1.77$ & $1.93 \pm 0.94$ & $6.54 \pm 1.28$ & $1.43 \pm 0.20$ & $433.1 \pm 56.5$ & $26.15 \pm 5.11$ & $5.70 \pm 0.79$ \\
\hline $\begin{array}{c}14 \mathrm{Apr}-24 \text { May } \\
\text { mean } \pm \text { s.d. }\end{array}$ & $0.50 \pm 0.20$ & $0.12 \pm 0.02$ & $644.5 \pm 113.9$ & $4.67 \pm 0.86$ & $1.57 \pm 0.54$ & $6.00 \pm 0.88$ & $1.50 \pm 0.07$ & $498.2 \pm 83.9$ & $24.00 \pm 3.52$ & $5.98 \pm 0.28$ \\
\hline
\end{tabular}

Criterion defined by mean and peak $\mathrm{NH}_{4}$ uptake (Fig. 6a, horizontal dotted lines).

Using the discrete measurements of $\mathrm{NH}_{4}$ concentrations at DWRD4 (entrance to Suisun Bay) and Delta Outflow, a more direct estimate of the $\mathrm{NH}_{4}$ loading to Suisun Bay for the same period in spring 2010 was calculated (Eqns. (3) and (4)). This directly estimated $\mathrm{NH}_{4}$ loading declined from $2.79 \mathrm{mmol} \mathrm{m}^{-2} \mathrm{~d}^{-1}$ on 7 April prior to the bloom period, to $0.91 \mathrm{mmol} \mathrm{m}^{-2} \mathrm{~d}^{-1}$ at the end of the bloom period (Table 2, Fig. 6a). During the bloom period, it fell within the Loading Criterion range (only slightly above the peak criterion line on 12 April) (Fig. 6a). The overall mean directly estimated $\mathrm{NH}_{4}$ loading from March through May $\left(1.73 \pm 0.69 \mathrm{mmol} \mathrm{m}^{-2} \mathrm{~d}^{-1}\right.$ )(Table 2), is close to the value estimated assuming 15 tons $\mathrm{NH}_{4}-\mathrm{N} \mathrm{d}^{-1}$ discharge at the WTP discharge location after accounting for nitrification losses of $\mathrm{NH}_{4}, 1.58 \mathrm{mmol} \mathrm{m}^{-2} \mathrm{~d}^{-1}$ (Table 1 ).

\subsubsection{Ammonium concentrations}

Although changes in river flow at SRWTP do not affect the calculated $\mathrm{NH}_{4}$ loading to Suisun Bay (with no export pumping), changes in flow at SRWTP affect the concentration of $\mathrm{NH}_{4}$ in the river as a result of dilution and these changes are propagated downstream. A rapid change in concentration (calculated from the SRWTP discharge and flow) occurred at SRWTP between 7 and 14 April when $\mathrm{NH}_{4}$ concentration declined by $\sim 30 \%$ from 30.95 to $20.63 \mu \mathrm{mol} \mathrm{L}^{-1}$ (Table 2, Fig. 6b). The discharge at SRWTP decreased only slightly from $6.61-6.22 \mathrm{mmol} \mathrm{m}^{-2} \mathrm{~d}^{-1}$ between these dates and could not have caused such a change in concentration at SRWTP (Table 2, Fig. 6b). The change in concentration was the result of rapid increase in flow at the SRWTP (from 418.9 to $591.6 \mathrm{~m}^{3} \mathrm{~s}^{-1}$ ) (Fig. 6b, Table 2). Between 7 and 14 April the calculated $\mathrm{NH}_{4}$ concentrations at DWR-D4 also declined, from 7.74 to $5.16 \mu \mathrm{mol} \mathrm{L}^{-1}$ (Table 2) and the measured concentration of $\mathrm{NH}_{4}$ declined nearly $50 \%$ from 9.66 to $5.50 \mu \mathrm{mol} \mathrm{L}^{-1}$ as river flow at DWR-D4 (i.e. Delta Outflow) increased from $567.0-759.7 \mathrm{~m}^{3} \mathrm{~s}^{-1}$.

Both measured and calculated $\mathrm{NH}_{4}$ concentrations at DWR-D4 fell slightly above the Concentration Criterion, $4 \mu \mathrm{mol} \mathrm{L}{ }^{-1}$, with measured concentrations near the criterion value from the first bloom period in April to the second bloom in late May. The overall mean $\mathrm{NH}_{4}$ concentration $\left(6.52 \pm 2.59 \mu \mathrm{mol} \mathrm{L}^{-1}\right)$ that was measured at the overall mean river flow (543.2 $\pm 173.8 \mathrm{~m}^{3} \mathrm{~s}^{-1}$, Table 2$)$ is in good agreement with the predicted $\mathrm{NH}_{4}$ concentrations at the entrance to Suisun Bay assuming 15 tons $\mathrm{NH}_{4}-\mathrm{N} \mathrm{d}^{-1}$ discharge and $500 \mathrm{~m} \mathrm{~s}^{-1}$ river flow $\left(6.20 \mu \mathrm{mol} \mathrm{L}^{-1}\right.$,Table 1$)$ at DWR-D4.

\subsubsection{Washout flow}

The highest river flow at DWR-D4, on April 14, $759.7 \mathrm{~m}^{3} \mathrm{~s}^{-1}$ (Table 2), was well below the present Washout Criterion threshold, $1100 \mathrm{~m}^{3} \mathrm{~s}^{-1}$. For the rest of the period flows into Suisun Bay were about $50 \%$ of the washout thresholds.

\section{Discussion}

\subsection{Overview}

Two diatom blooms were observed in Suisun Bay in spring 2010. Ammonium loading was within the criteria limits set by mean and peak $\mathrm{NH}_{4}$ uptake capacity of the phytoplankton. $\mathrm{NH}_{4}$ concentrations in Suisun Bay in April were near the Concentration Criterion (4 $\mu \mathrm{mol} \mathrm{L}{ }^{-1}$ ) predicted to enable blooms. Washout was clearly avoided and river flow was below the current Washout flow Criterion. The major trigger was a sudden decline in both measured and predicted $\mathrm{NH}_{4}$ concentration at the entrance to Suisun Bay (DWR-D4), the result of rapid increases in flow at both SRWTP and Delta Outflow (Fig. 6b, Table 2). Ammonium concentrations continued to decline throughout the bloom period to about $1 \mu \mathrm{mol} \mathrm{L}^{-1}$ (Figs. 3 and 4). The 2010 bloom followed the sequence described by Dugdale et al. (2007) in which $\mathrm{NH}_{4}$ initially declined and chlorophyll biomass started to increase. When $\mathrm{NH}_{4}$ concentration was reduced to $1 \mu \mathrm{mol} \mathrm{L} \mathrm{L}^{-1} \mathrm{NO}_{3}$ was used and chlorophyll biomass increased rapidly.

\subsection{The $\mathrm{NH}_{4}$ paradox}

The observation that high $\mathrm{NH}_{4}$ concentrations, in the presence of ample $\mathrm{NO}_{3}$, results in reduced algal productivity is counterintuitive and requires explanation, since it is well known that when most algae are grown in batch culture on a medium containing both $\mathrm{NH}_{4}$ and $\mathrm{NO}_{3}, \mathrm{NH}_{4}$ will be taken up first and when exhausted $\mathrm{NO}_{3}$ will be taken up. The physiological process that reduces or eliminates phytoplankton $\mathrm{NO}_{3}$ use is generally referred to as $\mathrm{NH}_{4}$ inhibition of $\mathrm{NO}_{3}$ uptake (e.g. Eppley et al., 1979; Dortch, 1990; Cochlan and Bronk, 2003) and may occur at $\mathrm{NH}_{4}$ concentrations as low as $0.1-0.3 \mu \mathrm{mol} \mathrm{L}^{-1}$ (Wheeler and Kokkinakis, 1990). 

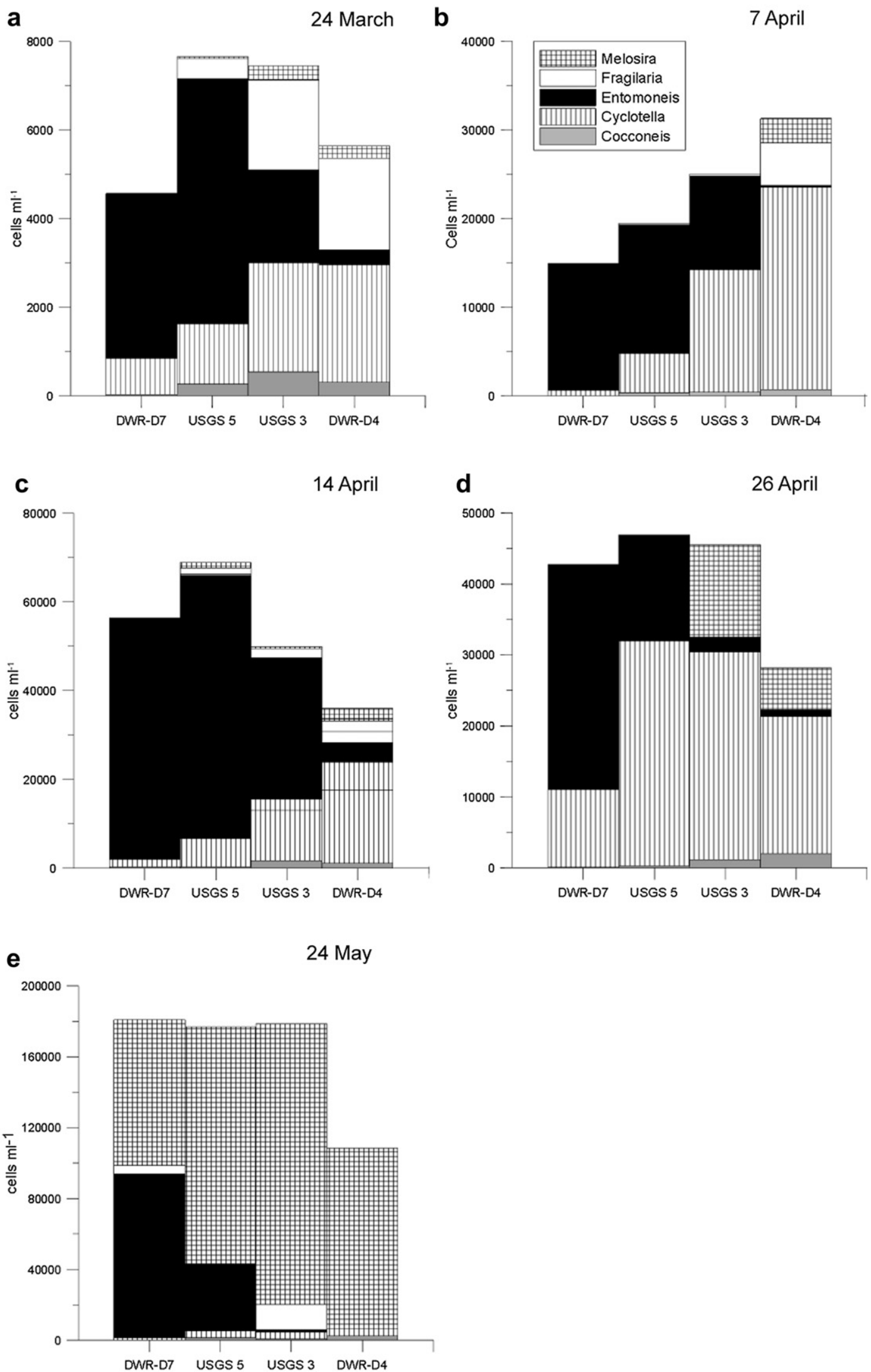

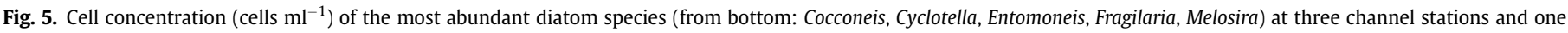
shoal station (DWR-D7) collected in 2010 on a) 24 March, b) 7 April, c) 14 April, d) 26 April and e) 24 May. 


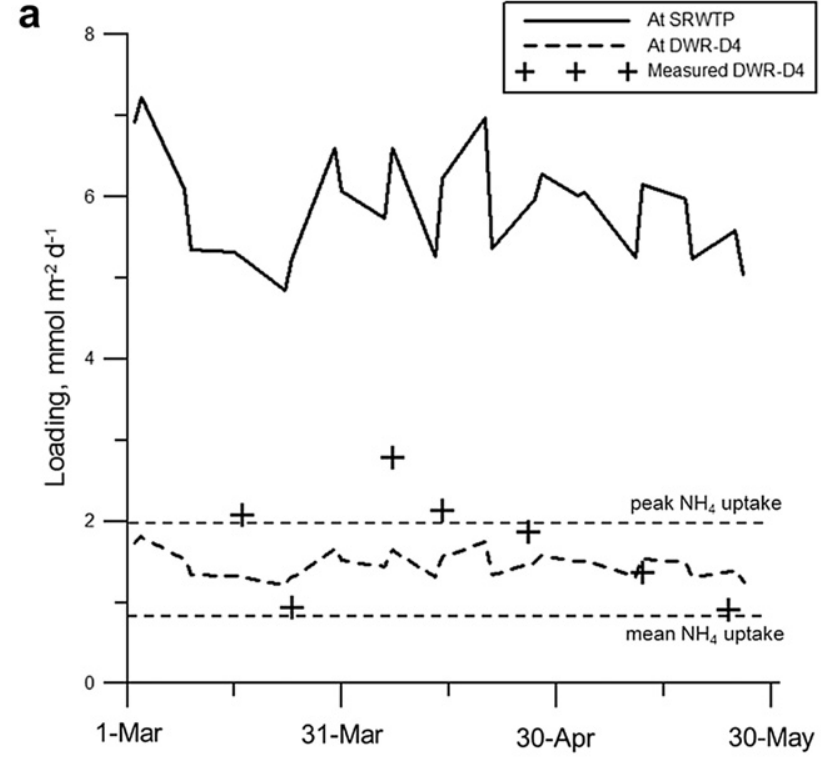

b

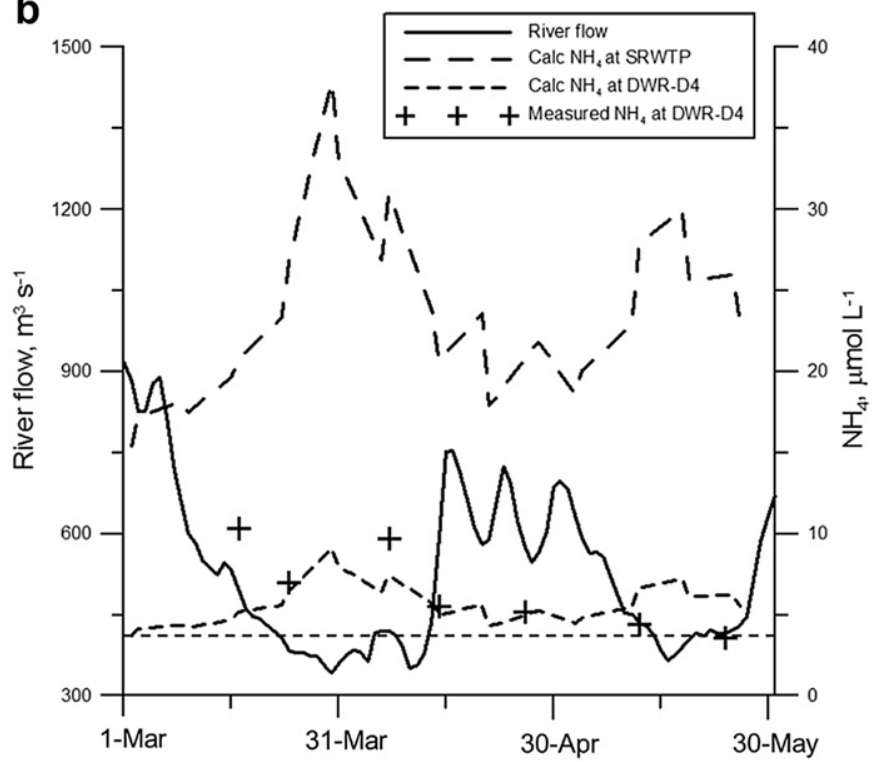

Fig. 6. a). Ammonium loading calculated at SRWTP and at station DWR-D4 (entrance to Suisun Bay) from discharge and river flow; DWR-D4 loading values (in crosses) calculated using $\mathrm{NH}_{4}$ concentration at DWR-D4 and Delta Outflow, overlaid with horizontal dotted lines with mean and peak phytoplankton $\mathrm{NH}_{4}$ uptake rates for Suisun Bay indicating the loading criterion to be met. b) River flow at the SRWTP with calculated (predicted) $\mathrm{NH}_{4}$ concentration at SRWTP and DWR-D4, and measured $\mathrm{NH}_{4}$ at DWR-D4 (crosses). The concentration criterion of $4 \mu \mathrm{mol} \mathrm{L}^{-1}$ is shown as a horizontal dotted line.

When both $\mathrm{NH}_{4}$ and $\mathrm{NO}_{3}$ are fully assimilated, the yield of algae is the sum of the commonly considered inorganic nitrogen forms (typically $\mathrm{NH}_{4}$ plus $\mathrm{NO}_{3}$ ). In a lake or lagoon, the progression of $\mathrm{NH}_{4}$ and $\mathrm{NO}_{3}$ uptake and algal production would follow that of the laboratory culture flask, providing no other nutrient becomes limiting. However, in a river or estuary, nutrients are refreshed from source regions by flow and the relative proportions of $\mathrm{NH}_{4}$ and $\mathrm{NO}_{3}$ become important. For example, consider source water flowing into a bay containing a 50:50 mixture of $\mathrm{NH}_{4}$ and $\mathrm{NO}_{3}, 20 \mu \mathrm{mol} \mathrm{L} \mathrm{L}^{-1}$ in each component. If the flow rate is low enough to allow phytoplankton biomass to accumulate and take up first all $\mathrm{NH}_{4}$ and then all $\mathrm{NO}_{3}, 40 \mu \mathrm{mol} \mathrm{L} \mathrm{L}^{-1}$ of phytoplankton $\mathrm{N}$ will be produced. This is equivalent to $40 \mu \mathrm{g} \mathrm{L}^{-1}$ chlorophyll $(1 \mu \mathrm{mol} \mathrm{N}$ removed produces $\sim 1 \mu \mathrm{g} \mathrm{L}^{-1}$ chlorophyll; see Dugdale and Goering, 1970; Marra et al., 1990 and refs therein). However, if the flow is sufficiently high to prevent full biomass accumulation (i.e. residence time is short), $\mathrm{NH}_{4}$ may remain at concentrations sufficient to block $\mathrm{NO}_{3}$ uptake. The $20 \mu \mathrm{mol} \mathrm{L}-1$ of $\mathrm{NO}_{3}$ is unused and flows out of the system. The maximum phytoplankton biomass ( $\sim$ chlorophyll) would depend only on the $\mathrm{NH}_{4}$ taken up, a maximum of $20 \mu \mathrm{mol} \mathrm{L} \mathrm{L}^{-1} \mathrm{NH}_{4}$ in the inflowing source water (a maximum of $20 \mu \mathrm{g} \mathrm{L}^{-1}$ chlorophyll). In this way, high $\mathrm{NH}_{4}$ results in less than maximal chlorophyll and productivity.

\subsection{Diatom contribution and distribution}

Diatoms made up virtually all of the phytoplankton (72-100\% of the phytoplankton counted) during the bloom periods, consistent with recent phytoplankton studies in the SFE (Cloern and Dufford, 2005) and with historic studies (Ball and Arthur, 1979). The diatoms observed included benthic Cocconeis and Entomoneis. Lidstrom (2008) also observed an abundance of Entomoneis in Suisun Bay in 2007. Two of the dominant diatom genera described in Ball and Arthur (1979), Melosira and Cyclotella, were also dominant in the Suisun 2010 bloom. From Fig. 3a-e it appears that the April 2010 bloom began in the channel of the central part of Suisun Bay and then was observed at the shoal station.

\subsection{Comparison of 2009 and 2010}

No bloom was observed in 2009 and some comparisons can be made for 2009 with criteria parameters and environmental conditions during the bloom year 2010. Loading Criteria for 2009 compared to 2010 can be evaluated from average April SRWTP discharge rates. No direct estimates of loading at DWR-D4 are available since no detailed sampling of Suisun Bay was made in 2009. The average discharge of $\mathrm{NH}_{4}$ from SWRTP declined by $7 \%$ in 2010 compared to 2009, and the loading to Suisun Bay declined by the same amount (Table 3 ).

The average river flow rate at SRWTP in April was 50\% higher in 2010 compared to 2009 (Fig. 7a, Table 3). The temporal pattern of flow also was different in the March to May periods of the two years. In 2009 flow declined to a low level and remained low until a single peak in early May. In 2010, a March low flow was followed by a sharp increase in mid-April declining by the end of May, the flow increase thought to be the trigger for the 2010 bloom. The effect of different flow patterns is shown by the trends in $\mathrm{NH}_{4}$ concentration at the effluent discharge location from March to June of 2009 and 2010 (Fig. 7b). The decline in $\mathrm{NH}_{4}$ concentration in 2010 in April does not occur in 2009 due to the lack of increased flow in April 2009.

Table 3

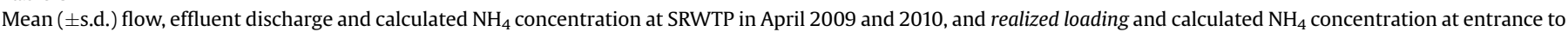
Suisun Bay.

\begin{tabular}{|c|c|c|c|c|c|c|}
\hline & \multirow[t]{2}{*}{ Flow $\mathrm{m}^{3} \mathrm{~s}^{-1}$} & \multicolumn{2}{|c|}{ Effluent discharge $^{\mathrm{a}}$} & \multirow[t]{2}{*}{$\mathrm{NH}_{4}$ at SRWTP $\mu \mathrm{mol} \mathrm{L}^{-1}$} & \multirow{2}{*}{$\begin{array}{l}\text { Realized loading to Suisun Bay } \\
\mathrm{mmol} \mathrm{m}^{-2} \mathrm{~d}^{-1}\end{array}$} & \multirow{2}{*}{$\begin{array}{l}\mathrm{NH}_{4} \text { at Suisun Bay } \\
\text { (DWR-D4) } \mu \mathrm{mol} \mathrm{L}^{-1}\end{array}$} \\
\hline & & $\overline{10^{6} \mathrm{~mol} \mathrm{~N} \mathrm{~d}^{-1}}$ & Tons $\mathrm{N} \mathrm{d}^{-1}$ & & & \\
\hline 2009 & $345 \pm 37$ & $1.11 \pm 0.26$ & 15.54 & $37.62 \pm 9.67$ & 1.63 & 9.41 \\
\hline 2010 & $518 \pm 80$ & $1.03 \pm 0.10$ & 14.42 & $23.38 \pm 4.10$ & 1.51 & 5.85 \\
\hline
\end{tabular}

\footnotetext{
${ }^{\text {a }}$ Calculated from daily data from SRWTP.
} 


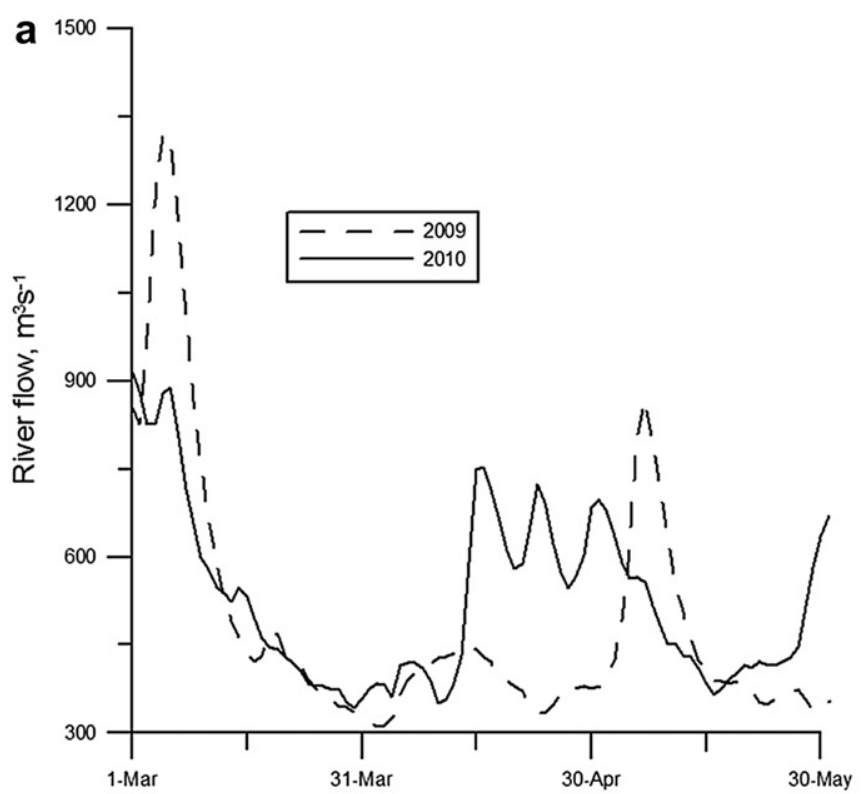

b

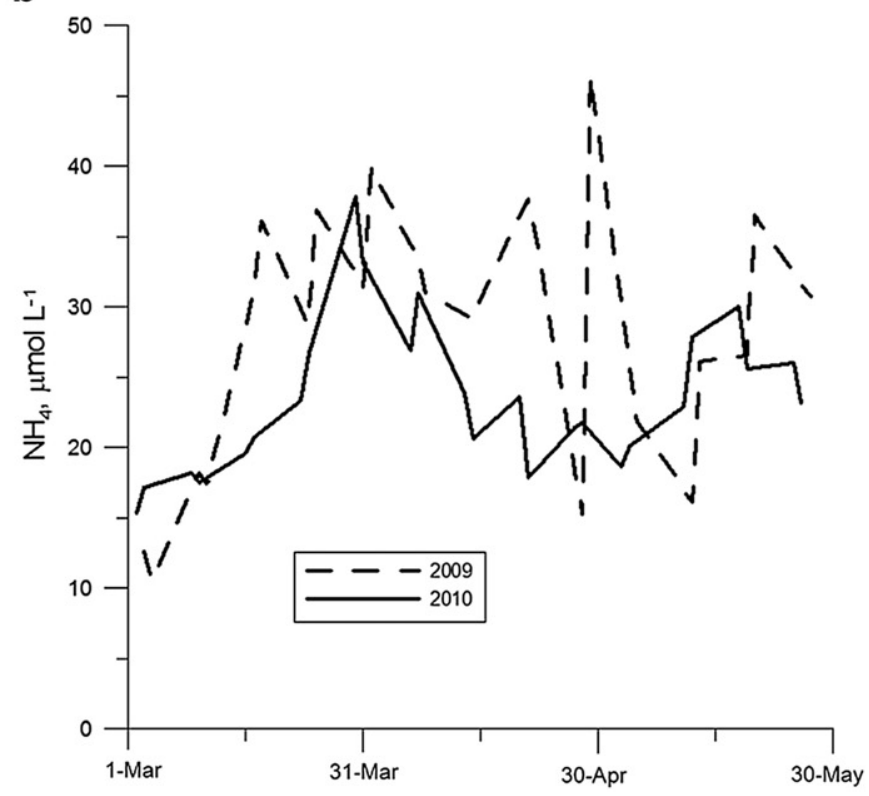

Fig. 7. Comparison of 2009 (dashed line) and 2010 (solid line) at SRWTP of a) River flow and b) $\mathrm{NH}_{4}$ concentration calculated from the daily effluent $\mathrm{NH}_{4}$ discharge and river flow.

Flow rates were below the current Washout Criterion, $1100 \mathrm{~m}^{3} \mathrm{~s}^{-1}$, during the 2010 study period (Fig. 7a) and the same was true for the spring period in 2009 except for early March (Fig. 7a). The interaction between calculated $\mathrm{NH}_{4}$ concentration, discharge and flow can be visualized using the data for 2009 and 2010 (Fig. 8). The two hyperbolae were calculated for the mean April 2009 and 2010 estimates of discharge at SRWTP (Table 3). The $\mathrm{NH}_{4}$ concentrations at SRWTP calculated from the daily discharge and flow data are shown. Some of the data for 2010 (crosses) falls below the hyperbola drawn through the mean conditions, indicating that during the study period in April 2010 discharge was reduced below the average value. The horizontal dotted line drawn from the $y$-axis at $16 \mu \mathrm{mol} \mathrm{L}{ }^{-1}$ is the $\mathrm{NH}_{4}$ concentration at SRWTP required to meet the Concentration Criterion at the entrance to Suisun Bay. The vertical dotted line indicates the flow $\left(\sim 760 \mathrm{~m}^{3} \mathrm{~s}^{-1}\right)$ required to reduce the concentration of $\mathrm{NH}_{4}$ to

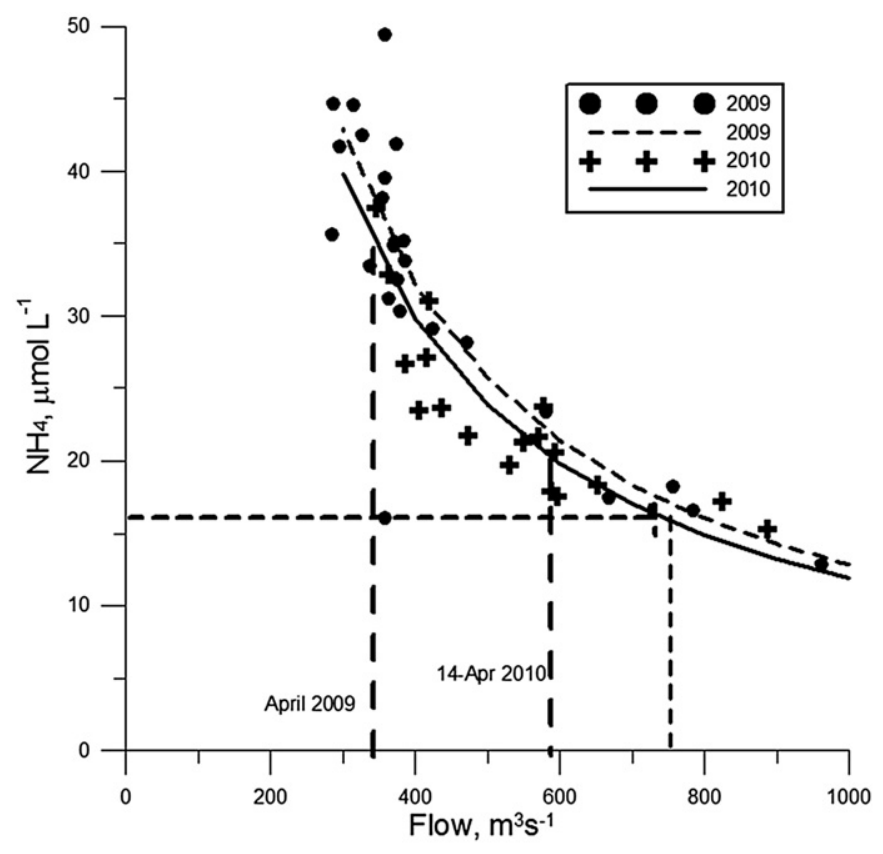

Fig. 8. Calculated concentration of $\mathrm{NH}_{4}$ during March to May of 2009 (circles) and 2010 (crosses) at SRWTP versus river flow. Two hyperbolae were calculated using the average SRWTP discharge for April 2009 and 2010 (Table 3). The horizontal dashed line at $16 \mu \mathrm{mol} \mathrm{L}^{-1}$ corresponds to the $4 \mu \mathrm{mol} \mathrm{L}^{-1}$ Concentration Criterion realized at Suisun Bay. The vertical dashed lines designate mean April flow in 2009 and on 14 April 2010. The dotted vertical line shows the flow necessary to meet the Concentration Criterion at mean discharge for April 2010.

$16 \mu \mathrm{mol} \mathrm{L} \mathrm{L}^{-1}$ at the discharge point and to $4 \mu \mathrm{mol} \mathrm{L}{ }^{-1}$ at DWR-D4 in Suisun Bay. The left-most vertical dashed line drawn at average river flow for April $2009\left(345 \mathrm{~m}^{3} \mathrm{~s}^{-1}\right)$ intersects the 2009 hyperbola at about $38 \mu \mathrm{mol} \mathrm{L}^{-1}$ (Table 3 ). The next vertical dashed line plotted for the river flow $\left(592 \mathrm{~m}^{-3} \mathrm{~s}^{-1}\right)$ at SRWTP on 14 April 2010, intersects the 2010 hyperbola above the Concentration Criterion (dotted horizontal line). In 2009 the flow was too low to meet the Concentration Criterion whereas in 2010 the higher flow and the likely lower discharge allowed concentrations close to the criterion to be met.

\subsection{Other factors that might influence the spring Suisun Bay blooms}

Other possible factors that might influence bloom occurrences are improved irradiance, physical processes, e.g. entrapment or fronts, and changes in the clam population density. The irradiance field in the SFE is determined primarily by the sediment load, except for times of high chlorophyll concentrations, when the latter will also decrease the water column transparency. The sediment load has decreased substantially in the northern SFE, and is predicted to continue to decline, leading to improved irradiance conditions (McKee et al., 2006; Jassby, 2008; Schoellhamer, 2009). However, increased irradiance does not always result in phytoplankton blooms (Ball and Arthur, 1979). From 1999 to 2002, Suisun Bay had a mean Secchi depth of $0.3 \mathrm{~m}$ in spring (Wilkerson et al., 2006). In 2010 Secchi depths were greater and averaged $0.7 \mathrm{~m}$ prior to the bloom (Table 2). Depth-integrated $\mathrm{NH}_{4}$ uptake rates were likely enhanced by the resultant deeper euphotic zone depth and this may have enabled the phytoplankton to meet the Loading Criterion.

Physical processes in addition to flow, which affects $\mathrm{NH}_{4}$ concentration and interacts with growth rate to determine the 
threshold flow for washout, will also play a role in bloom initiation. Mixing often results in a homogeneous water column in Suisun Bay. Transient water column stratification may act to not only improve the average water column irradiance conditions but also may concentrate the phytoplankton and aid bloom formation. Such increased biomass would result in an increase in $\mathrm{NH}_{4}$ uptake, another mechanism that would contribute to assimilation of the $\mathrm{NH}_{4}$ load. One candidate for such a mechanism is the particle entrapment zone or turbidity maximum, a feature of many estuaries. In the SFE, a salinity of 2 has been shown to coincide with the turbidity maximum and the distance from the Golden Gate where the bottom water salinity declines to 2 and is referred to as X2 (Kimmerer, 2002). X2 was within Suisun Bay during the historic bloom periods observed by Ball and Arthur (1979) for a range of river flows and also in this study (X2 $\sim 68 \mathrm{~km}$, water.ca.gov/dayflow). The 2010 data set described here was obtained from surface samples only and not useful for investigating vertical distributions of water properties. However Fig. 4a shows that the blooms occurred in surface water of $\leq 2$ suggesting that particle entrapment might have contributed to the bloom. A detailed study of the vertical salinity field during an ongoing bloom with nutrient and carbon uptake rate measurements is needed to better constrain the role of circulation and stratification in bloom development. Stratification would also create a barrier to benthic grazing on the phytoplankton.

The invasive clam, Potamocorbula amurensis (=Corbula amurensis) has been present in Suisun Bay since 1987 and considered the cause of the rapid decline in summer phytoplankton that occurred shortly after its introduction (Alpine and Cloern, 1992; Jassby et al., 2002). The clam population follows a seasonal cycle of growth and predation, with a biomass minimum in spring and biomass maximum in fall (e.g. Greene et al., 2011). The question arises; was the population lower in spring 2010 than 2009? In Suisun Bay similar population sizes were reported for spring 2009 and 2010, except for at DWR-D6 where the mean population of $P$. amurensis was higher in April $2010\left(6337 \pm 1226\right.$ individuals $\left.\mathrm{m}^{-2}\right)$ than April 2009 (5985 \pm 705 individuals $\mathrm{m}^{-2}$ ) (Fuller, Bay-Delta Monitoring and Analysis, California Department of Water Resources, pers. comm.). The similarity in clam abundance between years argues against reduced grazing on phytoplankton in 2010 as a cause for the bloom.

In summary, the major drivers of the spring 2010 bloom in Suisun Bay were increased river flow and decreased discharge of $\mathrm{NH}_{4}$ at SRWTP, enabling the phytoplankton population to absorb the inflowing $\mathrm{NH}_{4}$ and reduce the $\mathrm{NH}_{4}$ concentration to levels that would allow use of $\mathrm{NO}_{3}$. The populations that arose were very similar quantitatively and qualitatively (diatom dominated) to pre1987 Suisun blooms of phytoplankton.

\subsection{Food web response}

The cause(s) of the decline in pelagic fisheries in the northern SFE has so far eluded the scientific and management community. No sustained resurgence in fish populations has occurred in spite of extensive financial contributions towards habitat restoration and research (Sommer et al., 2007). The present study, in concert with other studies conducted in the northern SFE (Glibert et al., 2011; Parker et al., 2012c) suggests increased discharge of $\mathrm{NH}_{4}$ into the Sacramento River as a cause of reduced phytoplankton blooms and the subsequent food-limited conditions in Suisun Bay. When this $\mathrm{NH}_{4}$ discharge is reduced, the food web should respond positively. In May 2010, accompanying the observed phytoplankton blooms and lower $\mathrm{NH}_{4}$ loading, there was a nine-fold higher abundance of the zooplankton food source (calanoid copepod adults) for the pelagic fishes in Suisun Bay compared to May 2009 (Hennessey, CA
Dept. Fish and Game, pers. comm.), likely a result of the 2010 phytoplankton blooms described here. Eurytemora affinis increased from 32 individuals $\mathrm{m}^{-3}$ in May 2009 to 246 individuals $\mathrm{m}^{-3}$ in May 2010 and Sinocalanus doerri from 70 individuals $\mathrm{m}^{-3}$ in May 2009 to 1299 individuals $\mathrm{m}^{-3}$ in May 2010. Results from the 2010 Fall Midwinter Trawl Index for delta smelt and longfin smelt were $70 \%$ and $194 \%$ greater than those reported for 2009 (CA Dept. Fish and Game, dfg.ca.gov/delta/data/fmwt/charts.asp).

\subsection{Future predictions}

In December 2010, changes were approved to the SRWTP discharge permit requiring reductions in $\mathrm{NH}_{4}$ inputs to the Sacramento River both through nitrification and denitrification. Reductions in $\mathrm{NH}_{4}$ loadings should result in an increased probability of spring diatom blooms. Upgrading the SRWTP to full biological nitrogen removal (BNR, coupled nitrification/denitrification) would likely result in the Sacramento River phytoplankton productivity and community structure being driven by the conditions in the upper Sacramento River above the SRWTP (Parker et al., 2012c). These conditions of high $\mathrm{NO}_{3}$, low $\mathrm{NH}_{4}$ would likely fuel diatom blooms in Suisun Bay if the washout flow was not exceeded (i.e. the Washout Criterion) since both the Loading and Concentration Criteria would be met.

Increased irradiance conditions due to the expected decrease in sediment load (Schoellhamer, 2009) should result in an improved capacity of the phytoplankton to assimilate the $\mathrm{NH}_{4}$ load to Suisun Bay from the Sacramento River, thereby reducing $\mathrm{NH}_{4}$ concentrations to below $\mathrm{NO}_{3}$ threshold, and enabling phytoplankton $\mathrm{NO}_{3}$ use and blooms. The similarity in spring conditions occurring during the 2010 bloom (low $\mathrm{NH}_{4}$, high chlorophyll, diatom success) with spring conditions (high chlorophyll and diatom dominance) that were described by Ball and Arthur (1979) for Suisun Bay from 1969 to 1979 suggests that a reversion to a diatom-fueled food web should also result in a return to the pre-1979 food web that supported larger zooplankton and higher food quality for fish. Ball and Arthur (1979) give mean values of chlorophyll of $30-40 \mu \mathrm{g} \mathrm{L}^{-1}$ for Suisun Bay in spring and $40-100 \mu \mathrm{g} \mathrm{L}^{-1}$ in summer $1969-1979$ and according to Cloern and Cheng (1981) mean $\mathrm{NH}_{4}$ concentrations for this period were low, in summer 1.8 and $4.0 \mu \mathrm{mol} \mathrm{L}^{-1}$ in winter. These results suggest that the high concentrations of chlorophyll characteristic of the pre-1987 period could occur in spring if low $\mathrm{NH}_{4}$ conditions were restored to the river and flow conditions were within prescribed limits. Phytoplankton could be restored to high spring chlorophyll conditions in Suisun Bay and even to high summer values if the clams were to disappear, as has happened elsewhere when $\mathrm{NH}_{4}$ inputs were reduced (see case studies in Glibert, 2010). In this scenario, an increase in SFE productivity would follow the pattern of recovery observed in the Scheldt Estuary where nutrient inputs were reduced (Cox et al., 2009; Mialet et al., 2011). The present study provides an example of how the reduction of anthropogenic $\mathrm{NH}_{4}$ inputs may be employed to restore pre-existing productivity to SFE and similarly impacted estuaries and coasts.

\section{Acknowledgments}

This research was supported by the San Francisco Regional Water Quality Control Board and the Delta Stewardship Council (formerly CalFED) Grant 1039. We wish to thank Chris Foe for advice, Peter Otis and his crew for water sampling, graduate students Sarah Blaser, Erica Kress and Christina Buck for help with laboratory analyses and Debbie Bronk for her critical review of the manuscript. 


\section{References}

Alpine, A., Cloern, J., 1988. Phytoplankton growth rates in a light-limited environment, San Francisco Bay. Marine Ecology Progress Series 44, 167-173.

Alpine, A.E., Cloern, J.E., 1992. Trophic interactions and direct physical effects control phytoplankton biomass and production in an estuary. Limnology and Oceanography 37, 946-955.

Arar, E., Collins, G.B., 1992. In Vitro Determination of Chlorophyll a and Phaeophytin in Marine and Freshwater Phytoplankton by Fluorescence. USEPA Methods for Determination of Chemical Substances in Marine and Estuarine Environmental Samples. USEPA, Cincinnati, Ohio.

Ball, M.D., Arthur, J.F., 1979. Planktonic chlorophyll dynamics in the northern San Francisco Bay and Delta. In: Conomos, J. (Ed.), San Francisco Bay: The Urbanized Estuary Investigations into the Natural History of San Francisco Bay and Delta With Reference to the Influence of Man. Pacific Division, AAAS, San Francisco, pp. 265-286.

Bran Luebbe, Inc, 1999a. Bran Luebbe AutoAnalyzer Applications: AutoAnalyzer Method No. G-172-96 Nitrate and Nitrite in Water and Seawater. Bran Luebbe, Inc, Buffalo Grove, IL

Bran Luebbe, Inc, 1999b. Bran Luebbe AutoAnalyzer Applications: AutoAnalyzer Method No. G-175-96 Phosphate in Water and Seawater. Bran Luebbe, Inc, Buffalo Grove, IL.

Bran Luebbe, Inc, 1999c. Bran Luebbe Autoanalyzer Applications: AutoAnalyzer Method No. G-177-96 Silicate in Water and Seawater. Bran Luebbe, Inc, Buffalo Grove, IL.

Cloern, J.E., Cheng, R.T., 1981. Simulation model of Skeletonema costatum population dynamics in northern San Francisco Bay, California. Estuarine Coastal and Shelf Science $12,83-100$.

Cloern, J.E., Dufford, R., 2005. Phytoplankton community ecology: principles applied in San Francisco Bay. Marine Ecology Progress Series 285, 1-28.

Cochlan, W.P., Bronk, D.A., 2003. Effects of ammonium on nitrate utilization in the Ross Sea, Antarctica; implications for f-ratio estimates. Biogeochemistry of the Ross Sea, Antarctic Research Series 78, 159-178.

Cole, B.E., Cloern, J.E., 1987. An empirical model for estimating phytoplankton productivity in estuaries. Marine Ecology Progress Series 36, 299-305.

Cox, T., Maris, T., Soetaert, K., Conley, D., Van Damme, S., Meire, P., Middelburg, J. Vos, M., Struyf, E., 2009. A macro-tidal freshwater ecosystem recovering from hypereutrophication; the Schelde case study. Biogeosciences 6, 2935-2948.

Cupp, E.E., 1943. Marine Plankton Diatoms of the West Coast of North America. Otto Koeltz Science Publishers, University of California Press, Koenigstein.

Dortch, Q., 1990. The interaction between ammonium and nitrate uptake in phytoplankton. Marine Ecology Progress Series 61, 138-201.

Dugdale, R.C., Goering, J.J., 1970. Nutrient Limitation and the Path of Nitrogen in Peru Current Production. Scientific Results of the Southeast Pacific Expedition, Anton Brunn Report No 5, pp. 5.3-5.8.

Dugdale, R.C., Wilkerson, F.P., Hogue, V.E., Marchi, A., 2007. The role of ammonium and nitrate in spring bloom development in San Francisco Bay. Estuarine, Coastal and Shelf Science 73, 17-29.

Eppley, R.W., Renger, E.H., Harrison, W.G., Cullen, J.J., 1979. Ammonium distribution in southern California coastal waters and its role in the growth of phytoplankton. Limnology and Oceanography $24,495-509$.

Foe, C., Ballard, A., Fong, S., 2010. Nutrient Concentrations and Biological Effects in the Sacramento-San Joaquin Delta. Regional Water Quality Control Board Report, pp. 90.

Glibert, P.M., 2010. Long-term changes in nutrient loading an stoichiometry and their relationship with changes in the food web and dominant pelagic fish species in the San Francisco Estuary, California. Reviews in Fisheries Science 18, 211-232.

Glibert, P.M., Fullerton, D., Burkholder, J.M., Cornwell, J., Kana, T.M., 2011. Ecological stoichiometry, biogeochemical cycling, invasive species, and aquatic food webs: San Francisco Estuary and comparative systems. Reviews in Fisheries Science 19, 358-417.

Greene, V., Sullivan, L.J., Thompson, J.K., Kimmerer, W.J., 2011. Grazing impact of the invasive clam Corbula amurensis on the microplankton assemblage of the northern San Francisco Estuary. Marine Ecology Progress Series 431, 183-193.

Hager, S., Schemel, L., 1992. Sources of nitrogen and phosphorus to northern San Francisco bay. Estuaries 15, 40-52.

Hager, S., Schemel, L., 1996. Dissolved inorganic nitrogen, phosphorus and silicon in South San Francisco Bay I. Major factors affecting distributions. In: Hollibaugh, J.T. (Ed.), San Francisco Bay: The Ecosystem. Pacific Division, AAAS San Francisco, pp. 189-215.

Holm-Hansen, O., Lorenzen, C.J., Holmes, R.W., Strickland, J.D.H., 1965. Fluorometric determination of chlorophyll. Journal Conseil Permanente International Pour L' Exploration De La Mer 30, 3-5.

Jassby, A.D., 2008. Phytoplankton in the upper San Francisco Estuary: recent biomass trends, their causes and their trophic significance. San Francisco Estuary and Watershed Science 6,1-24. http://www.escholarship.org/uc/item/ 71h077r1.
Jassby, A.D., Cloern, J.E., Cole, B.E., 2002. Annual primary production: patterns and mechanisms of change in a nutrient-rich tidal ecosystem. Limnology and Oceanography $47,698-712$.

Kimmerer, W.J., 2002. Effects of freshwater flow on abundance of estuarine organisms: physical effects or trophic linkages? Marine Ecology Progress Series 243, 39-55.

Kimmerer, W.J., Ferm, N., Nicolini, M.H., Peñalva, C., 2005. Chronic food limitation of egg production in populations of copepods of the genus Acartia in the San Francisco Estuary. Estuaries 28, 541-550.

Kimmerer, W.J., Orsi, J., 1996. Causes of long term declines in zooplankton in the San Francisco Bay estuary since 1987. In: Hollibaugh, J.T. (Ed.), San Francisco Bay: The Ecosystem. Pacific Division, AAAS, San Francisco, pp. 403-424

Kimmerer, W.J., Parker, A.E., Lidstrom, U., Carpenter, E.J., 2012. Short-term and interannual variability in primary productivity in the low-salinity zone of the San Francisco Estuary. Estuaries and Coasts 35, 913-929.

Lidström, U.E. 2008. Primary Production, Biomass and Species Composition of Phytoplankton in the Low Salinity Zone of the Northern San Francisco Estuary. MSc thesis, San Francisco State University.

MacIsaac, J.J., Dugdale, R.C., Huntsman, S.A., Conway, H.L., 1979. The effect of sewage on uptake of inorganic nitrogen and carbon by natural populations of marine phytoplankton. Journal of Marine Science 37, 51-66.

Marra, J., Bidigare, R.R., Dickey, T.D., 1990. Nutrients and mixing, chlorophyll and phytoplankton growth. Deep-Sea Research Part A 37, 123-143.

McKee, L.J., Ganjub, N.K., Schoellhamer, D.H., 2006. Estimates of suspended sediment entering San Francisco Bay from the Sacramento and San Joaquin Delta, San Francisco Bay, California. Journal of Hydrology 323, 335-352.

Mialet, B., Gouzou, J., Azemar, F., Maris, T., Sossou, C., Toumi, N., Van Damme, S., Meire, P., Tackx, M., 2011. Response of zooplankton to improving water quality in the Scheldt estuary (Belgium). Estuarine, Coastal and Shelf Science 93, 47-57.

Müller-Solger, A., Jassby, A.D., Muller-Navarra, D., 2002. Nutritional quality of food resources for zooplankton (Daphnia) in a tidal freshwater system (SacramentoSan Joaquin River Delta). Limnology and Oceanography 47, 1468-1476.

Nixon, S., 1988. Physical energy inputs and comparative ecology of lake and marine ecosystems. Limnology and Oceanography 33, 1005-1025.

Parker, A.E., Hogue, V.E., Wilkerson, F.P., Dugdale, R.C., 2012a. The effect of inorganic nitrogen speciation on primary production in San Francisco Estuary. Estuarine, Coastal and Shelf Science 104-105, 91-101.

Parker, A.E., Kimmerer, W.J., Lidstrom, U., 2012b. Re-evaluating the generality of an empirical model for light-limited primary production in the San Francisco Estuary. Estuaries and Coasts 35, 930-942.

Parker, A.E., Wilkerson, F.P., Dugdale, R.C., 2012c. Elevated ammonium concentrations from wastewater discharge depress primary productivity in the Sacramento River and the northern San Francisco Estuary. Marine Pollution Bulletin 64, 574-586.

Pennock, J.R., 1987. Temporal and spatial variability in phytoplankton ammonium and nitrate uptake in the Delaware Bay. Estuarine, Coastal and Shelf Science 24, $841-857$.

Schoellhamer, D., 2009. Suspended sediment in the Bay: past a tipping point. In: The Pulse of the Estuary: Monitoring and Managing Water Quality in the San Francisco Estuary. San Francisco Estuary Institute, Oakland CA, pp. 56-65.

Solorzano, L., 1969. Determination of ammonia in natural waters by the phenolhypochlorite method. Limnology and Oceanography 14, 99-801.

Sommer, T.R., Armor, C., Baxter, R., Breuer, R., Brown, L., Chotkowski, M., Culberson, S., Feyrer, F., Gingas, M., Herbold, B., Kimmerer, W., Müller-Solger, A., Nobriga, M., Souza, K., 2007. The collapse of the pelagic fishes in the upper San Francisco Estuary. Fisheries 32, 270-276.

Utermöhl, H., 1958. Zur Vervollkommung der quantitative Phytoplankton Methodik. Mitt. Int. Verein. Limnol 9, 1-38.

Waiser, M.J., Tumber, V., Holm, J., 2010. Effluent-dominated streams. Part 1: presence and effects of excess nitrogen and phosphorus in Wascana Creek, Saskatchewan, Canada. Environmental Toxicology and Chemistry 30, 496-507.

Wheeler, P.A., Kokkinakis, S.A., 1990. Ammonium recycling limits nitrate use in the oceanic subarctic Pacific. Limnology and Oceanography 35, 1267-1278.

Whitledge, T.E., Malloy, S.C., Patton, C.J., Winck, C.D., 1981. Automated Nutrient Analyses in Seawater. Department of Energy and Environment, Brookhaven National Laboratory, Upton, NY.

Wilkerson, F.P., Dugdale, R.C., Hogue, V.E., Marchi, A., 2006. Phytoplankton blooms and nitrogen productivity in San Francisco Bay. Estuaries and Coasts 29, 401-4176.

Xu, J., Yin, K., Lee, J.H.W., Liu, H., Ho, A.Y.T., Yuan, X., Harrison, P.J., 2010. Long-term and seasonal changes in nutrients, phytoplankton biomass, and dissolved oxygen in Deep Bay, Hong Kong. Estuaries and Coasts 33, 399-416.

Yoshiyama, K., Sharp, J.H., 2006. Phytoplankton response to nutrient enrichment in an urbanized estuary: apparent inhibition of primary production by over eutrophication. Limnology and Oceanography 51, 424-434.

Yool, A., Martin, A.P., Fernandez, C., Clark, D.R., 2007. The significance of nitrification for oceanic new production. Nature 447, 999-1002. 